\title{
Properties of Ribbon and Non-Ribbon Release from Rod Photoreceptors Revealed by Visualizing Individual Synaptic Vesicles
}

\author{
Minghui Chen, ${ }^{1,2}$ Matthew J. Van Hook, ${ }^{2}$ David Zenisek, ${ }^{3}$ and Wallace B. Thoreson ${ }^{1,2}$ \\ Departments of ${ }^{1}$ Pharmacology and Experimental Neuroscience and ${ }^{2}$ Ophthalmology and Visual Sciences, University of Nebraska Medical Center, Omaha, \\ Nebraska 68198, and ${ }^{3}$ Department of Cellular and Molecular Physiology, Yale University School of Medicine, New Haven, Connecticut 06520
}

Vesicle release from rod photoreceptors is regulated by $\mathrm{Ca}^{2+}$ entry through L-type channels located near synaptic ribbons. We characterized sites and kinetics of vesicle release in salamander rods by using total internal reflection fluorescence microscopy to visualize fusion of individual synaptic vesicles. A small number of vesicles were loaded by brief incubation with FM1-43 or a dextran-conjugated, pH-sensitive form of rhodamine, pHrodo. Labeled organelles matched the diffraction-limited size of fluorescent microspheres and disappeared rapidly during stimulation. Consistent with fusion, depolarization-evoked vesicle disappearance paralleled electrophysiological release kinetics and was blocked by inhibiting $\mathrm{Ca}^{2+}$ influx. Rods maintained tonic release at resting membrane potentials near those in darkness, causing depletion of membrane-associated vesicles unless $\mathrm{Ca}^{2+}$ entry was inhibited. This depletion of release sites implies that sustained release may be rate limited by vesicle delivery. During depolarizing stimulation, newly appearing vesicles approached the membrane at $\sim 800 \mathrm{~nm} / \mathrm{s}$, where they paused for $\sim 60 \mathrm{~ms}$ before fusion. With fusion, vesicles advanced $\sim 18 \mathrm{~nm}$ closer to the membrane. Release events were concentrated near ribbons, but lengthy depolarization also triggered release from more distant nonribbon sites. Consistent with greater contributions from non-ribbon sites during lengthier depolarization, damaging the ribbon by fluorophore-assisted laser inactivation (FALI) of Ribeye caused only weak inhibition of exocytotic capacitance increases evoked by 200-ms depolarizing test steps, whereas FALI more strongly inhibited capacitance increases evoked by 25 ms steps. Amplifying release by use of non-ribbon sites when rods are depolarized in darkness may improve detection of decrements in release when they hyperpolarize to light.

\section{Introduction}

Changes in illumination are transduced by rod photoreceptors into membrane potential changes and encoded by altering the ongoing rate of synaptic vesicle release. Like cones, retinal bipolar cells, and hair cells, rods possess synaptic ribbons: electron-dense structures that assist in delivery, priming, and clustering of vesicles near L-type $\mathrm{Ca}^{2+}$ channels (Schmitz, 2009; Matthews and Fuchs, 2010). At these other ribbon synapses, both fast and slow components of vesicle release involve the ribbon (Khimich et al., 2005; Zenisek, 2008; Frank et al., 2010; Snellman et al., 2011). However, asynchronous release from bipolar cells can also occur at non-ribbon sites (Midorikawa et al., 2007; Zenisek, 2008). Mirroring their light response kinetics (Korenbrot and Rebrik, 2002), synaptic transmission is slower in rods than cones (Schnapf and

Received July 17, 2012; revised Nov. 6, 2012; accepted Dec. 5, 2012.

Author contributions: M.C., D.Z., and W.B.T. designed research; M.C., M.J.V.H., and W.B.T. performed research; M.C., M.J.V.H., D.Z., and W.B.T. analyzed data; M.C. and W.B.T. wrote the paper.

This research was supported by National Institutes of Health Grants EY010542 (W.B.T.), EY010542S1 (W.B.T.), and EY018111 (D.Z.), Research to Prevent Blindness (W.B.T.), and the Chinese Scholarship Council (M.C.).

The authors declare no competing financial interests.

Correspondence should be addressed to Wallace B. Thoreson, Department of Ophthalmology and Visual Sciences, University of Nebraska Medical Center, 4050 Durham Research Center I, Omaha, NE 68198-5840. E-mail: wbthores@unmc.edu.

DOI:10.1523/JNEUROSCI.3426-12.2013

Copyright $\odot 2013$ the authors $\quad 0270-6474 / 13 / 332071-16 \$ 15.00 / 0$
Copenhagen, 1982; Copenhagen et al., 1983; Rabl et al., 2005; Sheng et al., 2007). Slow, asynchronous release is often associated with larger distances between $\mathrm{Ca}^{2+}$ channels and release sites than fast, synchronous release (Eggermann et al., 2012), suggesting that slow release from rods might involve distant, non-ribbon sites. Consistent with contributions from non-ribbon sites to rod release, loss of anchored ribbons failed to completely abolish synaptic transmission (Dick et al., 2003), and electron tomography studies revealed exocytotic omega figures in non-ribbon regions of rod synapses (Zampighi et al., 2011). Furthermore, slow release from rods is amplified by $\mathrm{Ca}^{2+}$-induced $\mathrm{Ca}^{2+}$ release (CICR) involving endoplasmic reticulum located some distance from ribbons (Krizaj et al., 1999; Cadetti et al., 2006; Suryanarayanan and Slaughter, 2006; Babai et al., 2010).

We used total internal reflection fluorescence microscopy (TIRFM) to examine sites and kinetic properties of release from rods by visualizing individual vesicles loaded with FM1-43 (Cochilla et al., 1999) or a dextran-conjugated, pH-sensitive form of rhodamine (pHrodo). TIRFM has been used to study vesicle fusion in retinal bipolar cells (Zenisek et al., 2000, 2002; Holt et al., 2004; Midorikawa et al., 2007; Zenisek, 2008), synaptosomes (Serulle et al., 2007), and various non-neuronal cells (Steyer et al., 1997; Oheim et al., 1999; Schmoranzer et al., 2000; Toomre et al., 2000; Tsuboi et al., 2000; Becherer et al., 2003; Bezzi et al., 2004). 
Our results showed that, at membrane potentials near those in darkness, rods released vesicles continuously, primarily by fullcollapse fusion. Release sites were depleted by this slow ongoing release, implying that sustained release rates are governed by vesicle delivery, similar to cones (Jackman et al., 2009). Vesicle kinetics in rods exhibited both similarities and differences to other cell types. Newly arriving vesicles approached the membrane at $\sim 800 \mathrm{~nm} / \mathrm{s}$ and then paused for $\sim 60 \mathrm{~ms}$ before fusion. With exocytosis, vesicles advanced $\sim 18 \mathrm{~nm}$ closer to the membrane. Like other ribbon synapses, both fast and slow release occurred principally near the ribbon. However, contributions from nonribbon sites increased during lengthier stimulation. Diffusional spreading of glutamate released at distant non-ribbon sites may contribute to slow rod synaptic kinetics, but the amplification of release provided by use of ectopic sites may improve detection of decrements in release that accompany rod light responses.

\section{Materials and Methods}

Animal care and use. Male and female aquatic tiger salamanders (Ambystoma tigrinum, $18-25 \mathrm{~cm}$ in length; The Sullivan Company) were used for experiments. Protocols were approved by the University of Nebraska Medical Center Institutional Animal Care and Use Committee. Animals were maintained on a $12 \mathrm{~h}$ light/dark cycle and killed $1-2 \mathrm{~h}$ after the beginning of subjective night. Maintained illumination promotes disassembly of rod synaptic ribbons in some, although not all, animals (Abe and Yamamoto, 1984; Balkema et al., 2001; Spiwoks-Becker et al., 2004; Fuchs et al., 2013). Under dim room lights, salamanders were rapidly decapitated with heavy shears and immediately pithed.

Photoreceptor isolation and individual synaptic vesicle visualization. Using infrared illumination and night-vision goggles (Nitemate NAV3; Litton Industries) to maintain a dark-adapted state in the retina, the eye was enucleated, the front of the eye was removed, and the retina was isolated in an amphibian saline solution consisting of the following (in $\mathrm{mM}$ ): 116 $\mathrm{NaCl}, 2.5 \mathrm{KCl}, 1.8 \mathrm{CaCl}_{2}, 0.5 \mathrm{MgCl}_{2}, 10 \mathrm{HEPES}$, and 5 glucose, $\mathrm{pH} 7.8$. Unless otherwise specified, reagents were obtained from Sigma-Aldrich Chemicals.

Synaptic vesicles in rod terminals were loaded by incubating retinas with FM1-43 (30 $\mu \mathrm{M}$; Biotium) or a $10 \mathrm{kDa}$ dextran-conjugated, $\mathrm{pH}$ sensitive form of rhodamine (pHrodo, $500 \mu \mathrm{g} / \mathrm{ml}$; Invitrogen) at $20^{\circ} \mathrm{C}$. FM1-43 is incorporated into vesicles during endocytosis after the dye has been inserted into the plasma membrane. Vesicles then exhibit green fluorescence until the dye is released back into solution during exocytosis (Betz and Bewick, 1992; Cochilla et al., 1999). Dextran-conjugated pHrodo is water soluble and exhibits red fluorescence after endocytosis into the acidic interior of synaptic vesicles. Fluorescence of pHrodo is diminished considerably, but not completely quenched, at the extracellular $\mathrm{pH}$ of 7.8 .

Intact, dark-adapted rods in the retina have a relatively depolarized membrane potential in darkness of approximately $-45 \mathrm{mV}$ (Thoreson et al., 2000). Maintaining retinas in a dark-adapted state during the incubation period therefore stimulates the release of vesicles from rods accompanied by compensatory endocytosis and uptake of FM1-43 or pHrodo. After loading vesicles with dye, the retina was exposed to light to hyperpolarize rods and placed in a $\mathrm{Ca}^{2+}$-free saline solution to inhibit additional exocytosis. For most experiments, we used a short incubation time designed to load only a small fraction of the vesicle pool and thereby visualize individual vesicles. Measurements of FM1-43 uptake rates in darkness (Rea et al., 2004; Sheng et al., 2007) suggest that incubation for $1 \mathrm{~min}$ should load $<10 \%$ of the releasable vesicles in salamander rod terminals. An incubation period of 3 min was needed to load similar numbers of vesicles with the larger dextran-conjugated pHrodo. After plating rods onto glass coverslips, the number of dye-loaded vesicles slowly diminished as a result of the ongoing release of vesicles in $\mathrm{Ca}^{2+}$. containing amphibian saline solution. As described in Results, measurements of the tonic rate of release events in the absence of stimulation and the area of synaptic terminal membrane in contact with the glass suggest that $\sim 1-3 \%$ of vesicles were loaded with dye by the time experiments were conducted. In some experiments, we used longer $30 \mathrm{~min}$ incubation times to load a much larger percentage of the vesicle population.

After loading rods with dye, the retina was digested by incubation with papain $(30 \mathrm{U} / \mathrm{ml}$; Worthington) plus cysteine $(0.2 \mathrm{mg} / \mathrm{ml})$ in $\mathrm{Ca}^{2+}$-free amphibian saline for $35 \mathrm{~min}$ at $20^{\circ} \mathrm{C}$. After papain treatment, the tissue was washed in ice-cold, $\mathrm{Ca}^{2+}$-free amphibian saline containing $1 \%$ bovine serum albumin and DNase $(1 \mathrm{mg} / \mathrm{ml}$; Worthington), followed by two additional washes in ice-cold, $\mathrm{Ca}^{2+}$-free saline. To isolate photoreceptors, a piece of retina was carefully triturated using a fire-polished Pasteur pipette and the cell suspension transferred onto 1.78 refractive index glass coverslips (Olympus) coated with Cell-Tak (3.5 $\mu \mathrm{g} / \mathrm{cm}^{2}$; BD Biosciences). After letting cells settle and adhere for 30 $\mathrm{min}$, they were superfused with oxygenated amphibian saline solution at room temperature.

Solid-state lasers at 488 and $561 \mathrm{~nm}$ wavelengths (Melles Griot) were used to illuminate FM1-43- and pHrodo-loaded vesicles, respectively. The beam was focused off-axis onto the back focal plane of a 1.65 numerical aperture (NA) objective (Apo $100 \times$ oil; Olympus). After leaving the objective, light traveled through a high refractive index (1.78) immersion fluid (Cargille Laboratories) and entered the coverslip, undergoing total internal reflection at the interface between the glass and the lower refractive index of the cell membrane or overlying aqueous solution. Fluorescence emission was filtered by $525 \mathrm{~nm}$ ( $45 \mathrm{~nm}$ wide) or $609 \mathrm{~nm}$ (54 nm wide) bandpass filters (Semrock) and collected by an electronmultiplying CCD camera at 30-40 ms/frame (Hamamatsu ImageEM) with a pixel size of $80 \mathrm{~nm} /$ pixel. Data were acquired and analyzed using MetaMorph software (Molecular Devices).

We calculated the critical angle for total internal reflection $\left(\theta_{c}\right)$ from the following:

$$
\theta_{c}=\sin ^{-1}\left(n_{2} / n_{1}\right)
$$

where $n_{1}$ and $n_{2}$ are the indices of refraction for the glass coverslip $\left(n_{1}=\right.$ $1.78)$ and cytoplasm $\left(n_{2}=1.38\right.$; Bereiter-Hahn et al., 1979; Allersma et al., 2004). The incident angle of the laser $(\theta)$ was measured using Snell's law and a triangular (45-45-90) glass prism (Mattheyses and Axelrod, 2006). The length constant of the evanescent field depth (d) was calculated as follows:

$$
d=\frac{\lambda}{4 \pi n_{1}}\left(\sin ^{2} \theta-\sin ^{2} \theta_{c}\right)^{-1 / 2} .
$$

These measurements yielded length constants $(d)$ of 57 and $64 \mathrm{~nm}$ with $\lambda=488$ and $561 \mathrm{~nm}$ lasers, respectively.

Depolarizing stimulation. Depolarizing voltage steps or $50 \mathrm{~mm} \mathrm{KCl} \mathrm{puff}$ application were used to stimulate rods and evoke synaptic vesicle release. For puff application, patch pipettes were filled with an amphibian saline solution containing $50 \mathrm{~mm} \mathrm{KCl}$ and connected to a pressure valve system (Toohey) to control the duration and strength of the puff. The tip of the puffer pipette was positioned $10-20 \mu \mathrm{m}$ away from rod terminals. For application of depolarizing steps by voltage clamp $(-70$ to $-10 \mathrm{mV}$, 50 or $500 \mathrm{~ms}$ ), pipettes were pulled using a PP-830 vertical puller (Narishige International) from borosilicate glass pipettes (1.2 $\mathrm{mm}$ outer diameter, $0.9 \mathrm{~mm}$ inner diameter, with an internal filament; World Precision Instruments). Patch pipettes had tips of $\sim 2 \mu \mathrm{m}$ outer diameter and resistance values between 10 and $18 \mathrm{M} \Omega$. Each pipette was carefully positioned with an MP225 motorized micromanipulator (Sutter Instruments) so that the tip contacted the cell body. Rod membrane potential was voltage clamped using an A-M Systems model 2400 patch-clamp amplifier. Currents were acquired and analyzed using pClamp 8 software with a Digidata 1200 interface (Molecular Devices). Cells with holding currents $>300 \mathrm{pA}$ at $-70 \mathrm{mV}$ were rejected from analysis. The patch pipette solution contained the following (in $\mathrm{mm}$ ): 40 cesium glutamate, 50 cesium gluconate, 9.4 tetraethylammonium- $\mathrm{Cl}, 3.5 \mathrm{NaCl}, 1 \mathrm{CaCl}_{2}$, $1 \mathrm{MgCl}_{2}, 9.4$ ATP, 0.5 GTP, 5 EGTA, and 10 HEPES acid, pH 7.2. Both puff application and voltage steps were triggered by transistor-transistor logic (TTL) signals sent from the imaging computer. By measuring output from an LED placed on the microscope stage, we observed that the timing of the TTL trigger pulse sent by the imaging software jittered between two frames, often occurring with the image 
acquired $330 \mathrm{~ms}$ into the trial but sometimes occurring at $370 \mathrm{~ms}$ (average time point, $342 \mathrm{~ms}$ ).

Localization of ribbons. Two methods were used to localize ribbons. One was to label ribbons by introducing a fluorescently labeled peptide that binds to Ribeye, the major protein in the ribbon (Schmitz, 2009), into rods through a patch pipette. For these experiments, we used a high-affinity Ribeye-binding peptide constructed from tandem peptide dimers separated by a 12-polyethylene glycol linker and conjugated to Hylite 488 ([Hylite 488]-EQTVPVDLSARPR-PEG[12]EQTVPVDLSARPK-[Hylite 488], 250 nm; Francis et al., 2011). The second approach was to use sites of focal $\mathrm{Ca}^{2+}$ entry as an indication of ribbon location based on evidence that $\mathrm{Ca}^{2+}$ channels are clustered tightly beneath ribbons (Nachman-Clewner et al., 1999; Morgans, 2001; tom Dieck et al., 2005; Jackman et al., 2009; Mercer et al., 2011). To image $\mathrm{Ca}^{2+}$ entry sites, $100 \mu \mathrm{M}$ Fluo5F $\left(K_{d}=2.3 \mu \mathrm{M}\right.$; Invitrogen $)$ was added to the patch pipette solution. For Fluo5F experiments, images were obtained at $21 \mathrm{~ms} /$ frame by TIRFM. $\mathrm{Ca}^{2+}$ entry sites were identified from fluorescence increases evoked by $50 \mathrm{~ms}$ depolarizing steps from -70 to $-10 \mathrm{mV}$. Sites of focal $\mathrm{Ca}^{2+}$ entry were defined as locations showing the largest local depolarization-evoked $\mathrm{Ca}^{2+}$ change with $\Delta F / F$ of at least 0.5 . We distinguished different ribbons if focal $\mathrm{Ca}^{2+}$ entry sites were separated by $>500 \mathrm{~nm}$. Ribbons visualized with the fluorescently labeled, Ribeye-binding peptide were also separated by $>500 \mathrm{~nm}$.

Capacitance measurements of release. To measure release from rods electrophysiologically, we used a slice preparation from tiger salamander retina. Details of slice preparation and electrophysiological recordings have been described previously (Van Hook and Thoreson, 2013). Briefly, a section of eyecup was placed vitreal surface down on a piece of nitrocellulose filter paper $(5 \times 10 \mathrm{~mm}, 0.8 \mu \mathrm{m}$ pores; Millipore), and the retina was isolated under chilled amphibian saline. The retina and filter paper were cut into $125 \mu \mathrm{m}$ slices using a razor blade (\#121-6; Ted Pella) tissue chopper (Stoelting). Retinal slices were rotated $90^{\circ}$ to view the retinal layers under a long-working-distance, water-immersion objective $(60 \times, 1.0 \mathrm{NA})$ on an upright fixed-stage microscope (Nikon E600FN). Slices were superfused at $\sim 1 \mathrm{ml} / \mathrm{min}$ with the oxygenated amphibian saline solution described above.

We used capacitance measurement techniques to measure the increase in membrane capacitance accompanying vesicle fusion. Recording pipettes were coated with dental wax to reduce stray capacitance. Rods were voltage clamped at $-70 \mathrm{mV}$ with a pipette attached to the cell body using an OptoPatch amplifier (Cairn Research). Capacitance measurements were made using the "track-in" mode of the Optopatch amplifier by varying the membrane potential sinusoidally $(500 \mathrm{~Hz}, 30 \mathrm{mV}$ peak-topeak) about the mean holding potential. The amplitude of the capacitance change was measured in a $5 \mathrm{~ms}$ window $30 \mathrm{~ms}$ after the end of the test step to avoid effects of conductance changes and gating charges during the step and allow time for the phase angle feedback circuitry of the amplifier to settle. Membrane current, capacitance, and series resistance were acquired using a Digidata 1322 interface and pClamp 9.2 software (Molecular Devices). We excluded recordings in which the access resistance was $>50 \mathrm{M} \Omega$ and those that exhibited pronounced poststimulus changes in resistance.

Acute damage ribbon by fluorophore-assisted laser inactivation. To damage the ribbon by fluorophore-assisted laser inactivation (FALI), we used a fluorescein-conjugated Ribeye-binding peptide (EQTVPVDLSVARPR, 40 $\mu \mathrm{M})$ containing a PXDLS peptide sequence that binds to the C-terminal binding protein domain of Ribeye (Zenisek et al., 2004; Snellman et al., 2011). With FALI, excitation of the fluorescein moiety by $488 \mathrm{~nm}$ laser light generates singlet oxygen that causes highly localized damage, with half-maximal damage occurring within $\sim 40 \AA$ of the fluorophore (Hoffman-Kim et al., 2007). Either the Ribeye-binding peptide or a scrambled control peptide was added to the pipette solution together with the antioxidants, reduced glutathione $(1 \mathrm{~mm})$, and 6-hydroxy2,5,7,8-tetramethylchroman-2-carboxylic acid (Trolox, $1 \mathrm{~mm}$ ). Bleaching was done by $1 \mathrm{~min}$ exposure to $488 \mathrm{~nm}$ light from an argon/krypton laser delivered through a laser confocal scan head (Ultraview LCI; PerkinElmer Life and Analytical Sciences) mounted to an upright, fixedstage microscope (Nikon E600FN).
Statistical analyses. Data were analyzed using GraphPad Prism 4. Unless otherwise stated, results are presented as mean \pm SEM, and statistical significance between experimental conditions was determined using Student's $t$ test. The criterion for statistical significance was chosen to be $p<0.05$.

\section{Results}

\section{Fluorescent organelles are single synaptic vesicles}

In the synaptic terminals of isolated rods loaded with FM1-43 or dextran-conjugated pHrodo, small fluorescent organelles could be observed by TIRFM in the narrow evanescent field generated at the interface between the cell membrane and cover glass (illustrated diagramatically in Fig. $1 A$ ). With the 1.65 NA, $100 \times$ objective used for these experiments, the evanescent field declined exponentially with length constants of 57 and $64 \mathrm{~nm}$ for 488 and $561 \mathrm{~nm}$ lasers, respectively, not much larger than the $40-45 \mathrm{~nm}$ diameter of individual synaptic vesicles in rods (Lasansky, 1973; Thoreson et al., 2004).

To load only a small fraction of the $\sim 100,000$ vesicles in the rod terminal (Sheng et al., 2007), we incubated dark-adapted, whole retina for a short time (1 min for FM1-43, 3 min for pHrodo) in darkness. The relatively depolarized membrane potential of intact rods in darkness (approximately $-45 \mathrm{mV}$ ) stimulates synaptic release and compensatory endocytosis, promoting uptake of the dye. After this brief incubation, retinas were exposed to light and placed in $\mathrm{Ca}^{2+}$-free medium to inhibit additional exocytosis. As illustrated by the bright-field images in Figure 1, rods typically lost their outer segments, and thus lost light sensitivity, during the isolation procedure. Figure $1 C$ shows a higher-magnification view of the synaptic terminal of a rod that had been loaded with FM1-43 (enclosed by the box in Fig. 1B). The region of terminal membrane in contact with the glass coverslip created a faint fluorescent footprint that can be seen in the TIRFM image in Figure $1 D$ (average of 100 images acquired at 30 $\mathrm{ms} /$ frame). The bright spots in this average image reflect visits to the membrane by FM1-43-loaded organelles during the $3 \mathrm{~s} \mathrm{ac-}$ quisition period.

Mammalian rods have one to two ribbons per terminal, whereas isolated salamander rods have approximately seven ribbons per terminal, although only approximately 5 ribbons remain in contact with the plasma membrane after enzymatic isolation (Townes-Anderson et al., 1985). The two-dimensional area of terminals visualized in bright field averaged $39.7 \pm 2.5$ $\mu \mathrm{m}^{2}(n=11)$, suggesting a total terminal surface area $\left(A_{\text {terminal }}\right)$ that is at least twice as great. The footprint of membrane $\left(A_{\text {footprint }}\right)$ in contact with the coverslip in TIRFM in these same terminals averaged $28 \pm 2 \mu \mathrm{m}^{2}$ or $\sim 36 \pm 2 \%$ of the terminal surface area. The number of ribbons, $N$, predicted within the membrane footprint should be approximately $N=\frac{A_{\text {footprint }}}{A_{\text {terminal }}} \times 5=2.3 \pm 0.2(n=$ 11). To determine the number of ribbons empirically, we obtained whole-cell patch-clamp recordings and introduced a high-affinity, HyLite488-conjugated Ribeye-binding peptide (250 nM; Francis et al., 2011) into the cell. Fluorescently labeled ribbons were not visible in TIRFM, perhaps because their position atop the arciform density places them outside the evanescent field of illumination. However, we were able to see ribbons by angling the laser more steeply to illuminate the cell more deeply. Although visualized at a slightly deeper plane, we observed an average of $2.3 \pm 0.3(n=31)$ ribbons in the terminal area enclosed by the membrane footprint, matching the predicted number $(p=0.92)$.

Figure $1 E-G$ shows bright-field and TIRFM images of a rod loaded with dextran-conjugated pHrodo. Vesicles loaded with 

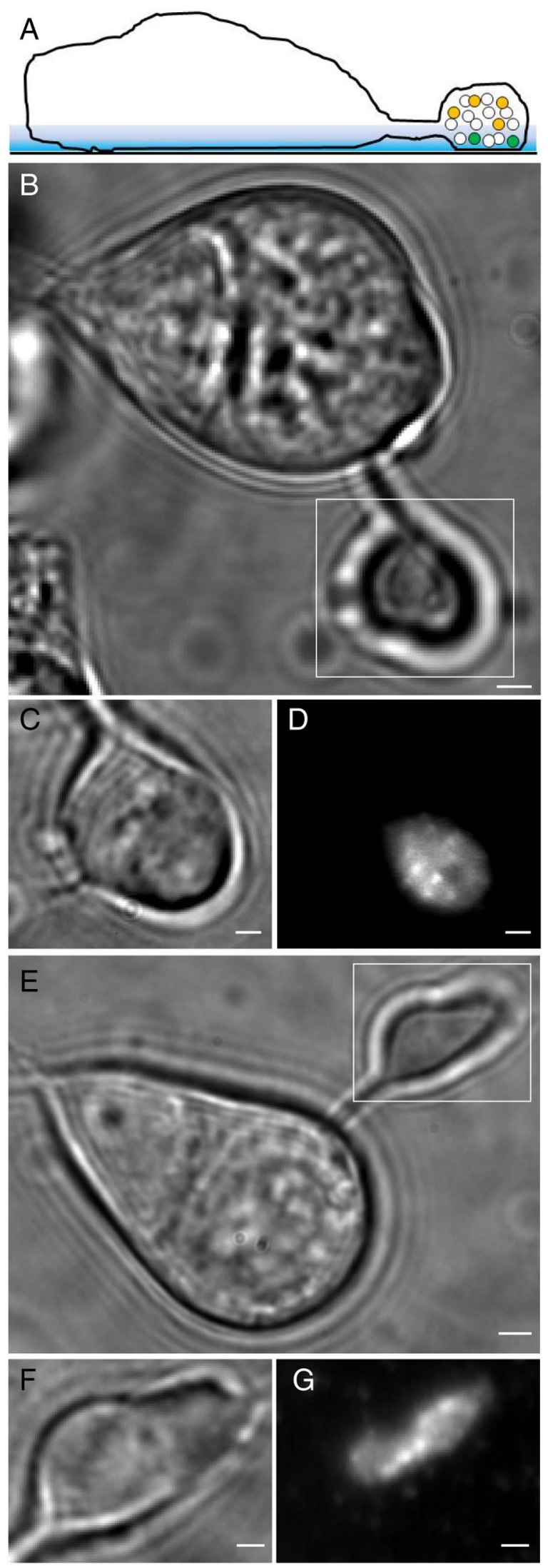

Figure 1. Bright-field and fluorescent images of rods loaded with FM1-43 or dextranconjugated pHrodo. A, Diagram illustrating a dye-loaded rod lying on a glass coverslip. Only a small number of vesicles in the synaptic terminal are loaded with dye (yellow and green circles), and only those vesicles (green circles) within the evanescent field of illumination (colored blue in the diagram) at the interface between the cell membrane and cover glass are visible by
pHrodo were slightly dimmer than those loaded with FM1-43, and so pHrodo images were acquired using a slightly longer frame duration of $40 \mathrm{~ms}$. Despite being dimmer, pHrodo generally provided better signal-to-noise. This may be because pHrodo produces less residual membrane staining than FM1-43 and because there is less cellular autofluorescence with longer wavelengths used to image pHrodo. We therefore used dextran-conjugated pHrodo for the majority of our experiments.

We compared the appearance of fluorescent organelles loaded with FM1-43 or dextran-conjugated pHrodo with small fluorescent microspheres that were similar in size to synaptic vesicles (Fig. 2). Fluorescence profiles were measured along a line placed through the center of the organelle or microsphere, aligned at their peaks, and fit with Gaussian functions. The widths at halfmaximum of FM1-43-loaded (369 $\pm 33 \mathrm{~nm}, n=9)$ and pHrodo-loaded $(373 \pm 11 \mathrm{~nm}, n=8)$ organelles did not differ significantly from those of $25 \mathrm{~nm}$ FM1-43-stained amine latex microspheres $(326 \pm 18 \mathrm{~nm}, n=14, p=0.22)$ and $40 \mathrm{~nm}$ red fluorescent microspheres $(370 \pm 13 \mathrm{~nm}, n=10, p=0.83$; Fig. $2 C, F)$, respectively. Thus, the size of fluorescently labeled organelles matched the diffraction-limited size of small fluorescent micropheres. The small, diffraction-limited size of fluorescent organelles, the narrow depth of the evanescent field $(\lambda=\sim 60$ $\mathrm{nm}$ ), and the small percentage of dye-loaded vesicles suggested that individual bright spots enclosed within 7-pixel-diameter $(560 \mathrm{~nm})$ regions were likely to be individual vesicles.

If these organelles are synaptic vesicles, then dye enclosed within them should be released when $\mathrm{Ca}^{2+}$ enters the terminal during depolarization. The image sequences in Figure 2 illustrate the disappearance of organelles loaded with FM1-43 or pHrodo in response to depolarization of rod terminals by puff application of $50 \mathrm{~mm} \mathrm{KCl}$. The time courses of fluorescence changes showed that fluorescence increased as dye-loaded organelles approached the membrane, moving deeper into the evanescent field. Fluorescence then decreased rapidly (Fig. $2 B, E$ ), consistent with fusion of an individual vesicle. To measure the time spent at or near the membrane surface by newly arriving vesicles before fusion, we measured the interval from when the fluorescence intensity reached $90 \%$ of its maximum until it had declined by $10 \%$. In a sample of vesicles released during application of high $\left[\mathrm{K}^{+}\right]$and exhibiting particularly good signal-to-noise, vesicle dwell time at or near the membrane was $\sim 60 \mathrm{~ms}$ (pHrodo, $61 \pm 7 \mathrm{~ms}, n=11$ vesicles; FM1-43, $69 \pm 8 \mathrm{~ms}, n=8$ vesicles; $p=0.46$ comparing pHrodo and FM1-43).

The speed of fluorescence decline was consistent with vesicle fusion. Figure 3, $A$ and $B$, shows the overlay of fluorescence declines from 15 FM1-43-loaded vesicles and 36 pHrodo-loaded vesicles. FM1-43 fluorescence declines were uniformly rapid (Fig. 3A). Fluorescence also declined very rapidly in the majority of pHrodo-loaded vesicles, although a handful showed more de-

TIRFM. B, Bright-field image of an isolated rod photoreceptor. Rods typically lost their lightsensitive outer segments during the isolation procedure, and so only the cell body, axon, and terminal remain. C, Higher-magnification view of the synaptic terminal (enclosed by the box in B). D, TIRFM image (average of 100 images acquired at $30 \mathrm{~ms} /$ frame) of the same synaptic terminal. The region of terminal membrane in contact with the glass coverslip made a faint fluorescent footprint. The bright spots in the image reflect visits to the membrane by FM1-43loaded organelles during the 3 s acquisition period. One can also see other inhomogeneities in FM1- 43 fluorescence, such as the dark area near the center of the terminal that may be attributable to regional differences in membrane adhesion to the glass or membrane composition. $\boldsymbol{E}-\boldsymbol{G}$ shows similar bright-field and TIRFM images of a rod loaded with dextran-conjugated pHrodo. Scale bars: $\boldsymbol{B}, \boldsymbol{E}, 2 \mu \mathrm{m} ; \boldsymbol{C}, \boldsymbol{D}, \boldsymbol{F}, \boldsymbol{G}, 1 \mu \mathrm{m}$. 

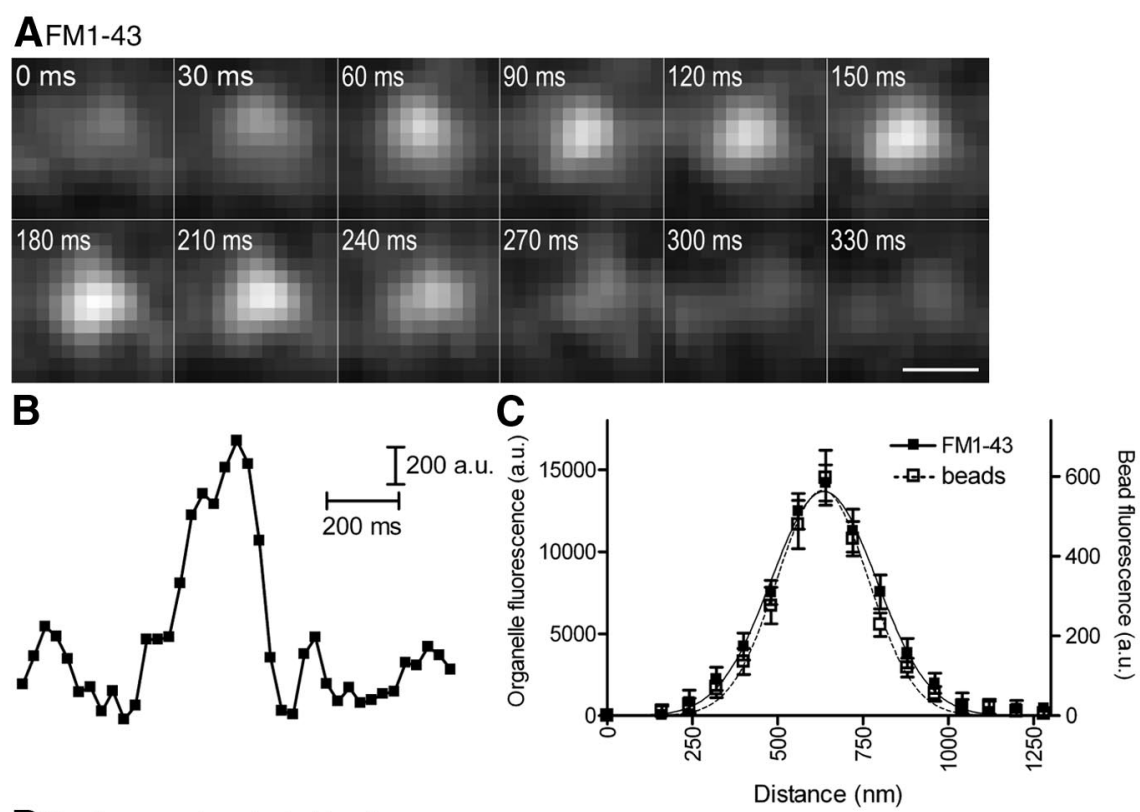

DDextran-conjugated pHrodo
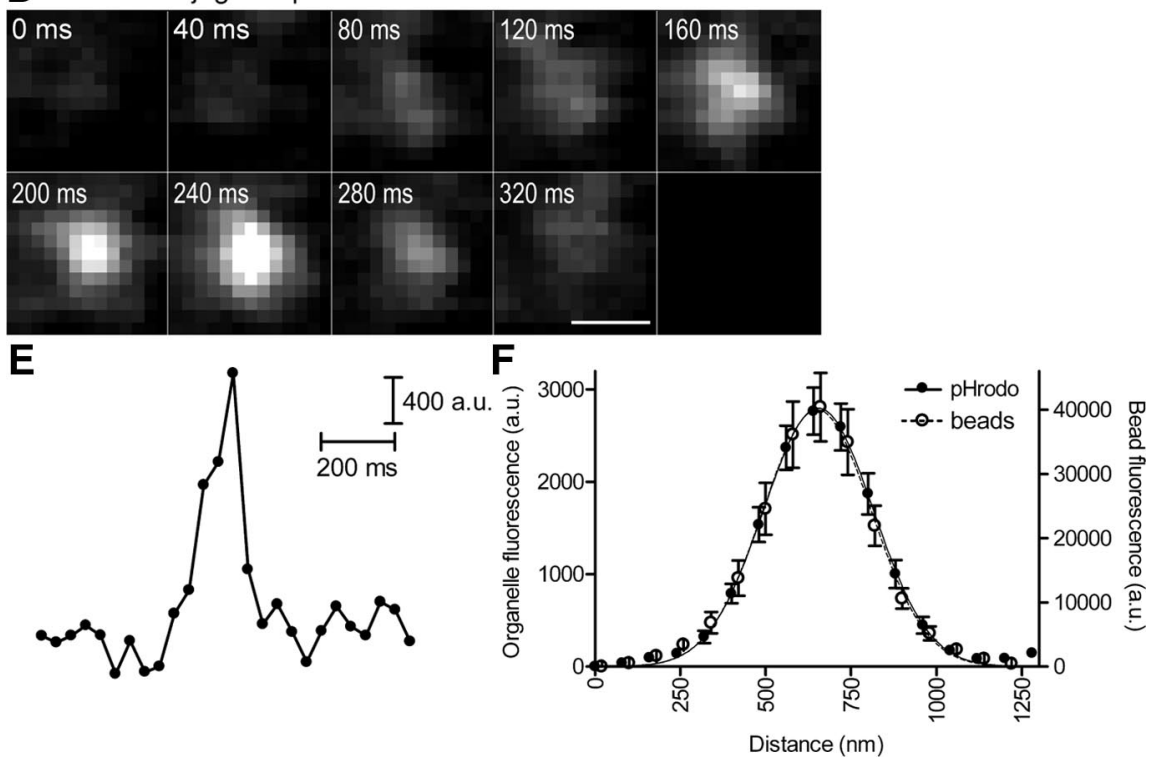

Figure 2. FM1-43- or pHrodo-labeled organelles had a diffraction-limited appearance that matched small fluorescent microspheres similar in size to synaptic vesicles. $A, D$, Consecutive images showing the disappearance of fluorescent organelles from rod terminals loaded with FM1 - $43(\boldsymbol{A})$ or dextran-conjugated pHrodo $(\boldsymbol{D})$ during $50 \mathrm{~mm}$ KCl puff. $\boldsymbol{B}, \boldsymbol{E}$, Changes in fluorescence plotted as a function of time for regions of interest enclosing FM1-43-stained $(\boldsymbol{B})$ or pHrodo-stained $(\boldsymbol{E})$ organelles. $\boldsymbol{C}, \boldsymbol{F}$, Fluorescence intensities measured along lines placed through the centers of FM1-43-stained ( $\boldsymbol{C}$, solid line) or pHrodo-stained ( $\boldsymbol{F}$, solid line) organelles, aligned at their peaks, and fit with Gaussian functions. Overlaid are fluorescence intensity profiles for $25 \mathrm{~nm} F M 1-43-$ stained amine latex microspheres ( $\boldsymbol{C}$, dashed line; Invitrogen) or $40 \mathrm{~nm}$ red microspheres ( $\boldsymbol{F}$, dashed line; FluoSpheres; Invitrogen). Scale bar, $0.5 \mu \mathrm{m}$.

layed fluorescence decreases (Fig. 3B). As illustrated for pHrodoloaded vesicles (Fig. $3 C$ ), the average rate of fluorescence decline observed with single vesicles (filled circles) was faster than the rate at which fluorescence intensity increased as vesicles approached the membrane (triangles). During membrane approach with pHrodo-loaded vesicles, fluorescence rose to $38.7 \pm$ $3.63 \%(n=27)$ of the maximum fluorescence two frames (82.6 $\mathrm{ms}$ ) before the peak intensity was attained. For pHrodo-loaded vesicles, fusion was defined as an abrupt decline in peak fluorescence intensity exceeding $60 \%$ within two frames with a total decrease of $>90 \%$ relative to baseline fluorescence. This defini- tion excluded a small number of slower fluorescence declines (Fig. 3B, open symbols; 5 of 36 or 14\%). Even when we included these few vesicles, the average rate of fluorescence decline was still more rapid than the rate of fluorescence increase caused by vesicle approach to the membrane (Fig. $3 C$, open squares). For newly arriving vesicles, baseline fluorescence was measured in the same area before vesicle appearance. For vesicles that were present at or near the membrane at the beginning of a trial, we used fluorescence in the surrounding membrane as a measure of baseline intensity. During membrane approach by FM1-43-loaded vesicles, fluorescence attained $47.3 \pm$ $0.60 \%(n=11)$ of the maximum fluorescence three frames $(93.9 \mathrm{~ms}$ ) before the peak. For FM1-43-loaded vesicles, we therefore defined vesicle fusion as a decline in fluorescence intensity of $>50 \%$ in three frames with a total decrease of $>90 \%$ relative to baseline fluorescence.

Fusion of a large group of vesicles should cause a slower reduction in fluorescence than fusion of an individual vesicle (Steyer et al., 1997). Fluorescence of pHrodo-loaded vesicles declined by $60 \%$ in $53 \mathrm{~ms}$ (Fig. 3C) and fluorescence of FM1-43-loaded vesicles declined by $60 \%$ in $63 \mathrm{~ms}$ (Fig. 3A), similar to kinetics of individual release events observed by TIRFM in bipolar cells (Zenisek et al., 2002; Midorikawa et al., 2007). In contrast, after loading a large number of vesicles by $30 \mathrm{~min}$ incubation with pHrodo, it took $615 \pm 16 \mathrm{~ms}(n=6)$ to achieve $60 \%$ fluorescence decline after a depolarization-evoked increase in nearmembrane fluorescence. Multiquantal release occurs less frequently in rods (Cadetti et al., 2005) than in hair cells or bipolar cells (Glowatzki and Fuchs, 2002; Singer et al., 2004), although the likelihood is increased in rods by activation of CICR (Suryanarayanan and Slaughter, 2006). Although the synchronous fusion of a few closely spaced vesicles might potentially generate a fluorescence decline with a rapid time course similar to fusion of an individual vesicle, the small percentage of dye-loaded vesicles suggests that most of the rapid disappearance events were attributable to the fusion of single vesicles.

Elevation of $\mathrm{Ca}^{2+}$ does not increase vesicle mobility at ribbon synapses (Holt et al., 2004; Rea et al., 2004). Together with our finding that fluorescence declines were more rapid than fluorescence increases caused by vesicle approach, this suggests that the increase in vesicle disappearance events was unlikely to be attributable to increased mobility and accelerated vesicle departure from the evanescent field. For additional confirmation that fluorescence declines involved exocytotic loss of pHrodo from vesicles, we used epifluorescence to look at dye-filled vesicles within 


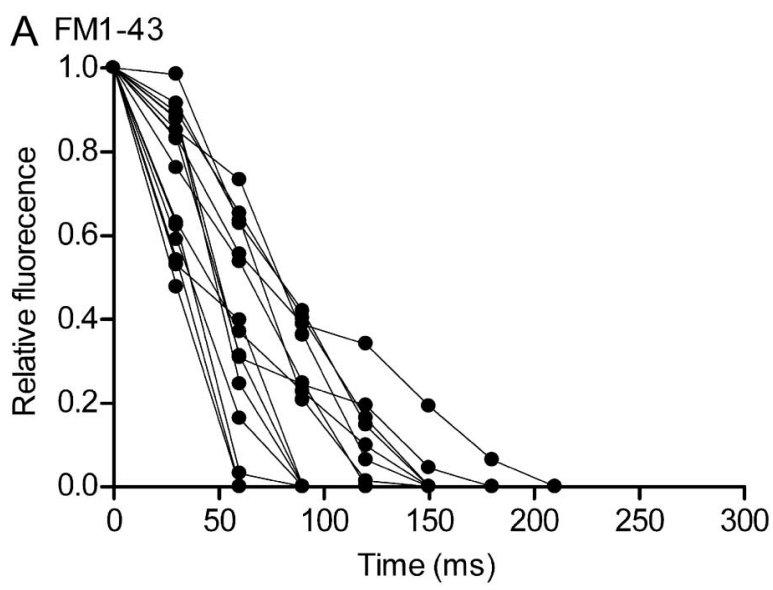

B pHrodo
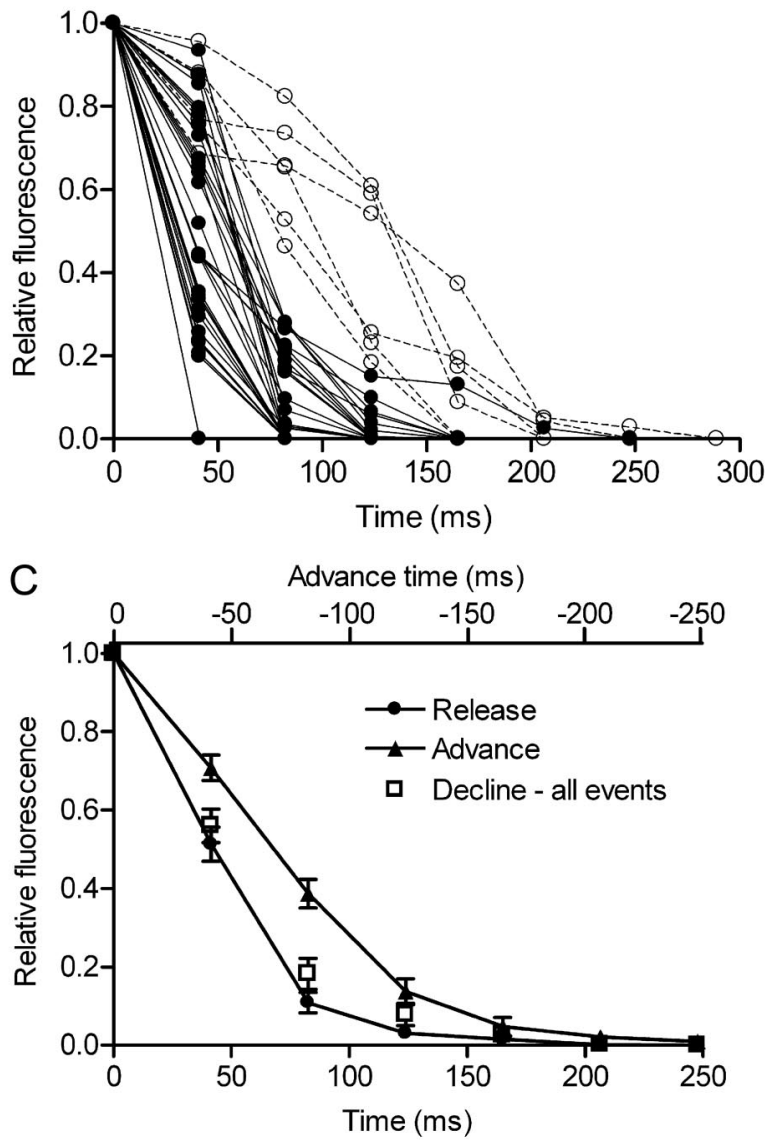

Figure 3. Fluorescence of dye-loaded organelles declined rapidly during depolarizing stimulation, consistent with fusion of individual vesicles. $\boldsymbol{A}, 0$ verlay of fluorescence declines from 15 FM1-43-loaded vesicles. Vesicle fusion for FM1-43-loaded vesicles was defined as an abrupt decline in peak fluorescence intensity exceeding $50 \%$ within three frames ( $94 \mathrm{~ms}$ ) with a total decrease of $>90 \%$ relative to baseline fluorescence (filled circles, $\boldsymbol{B}$ ). $\boldsymbol{B}, 0$ verlay of fluorescence declines from 36 pHrodo-loaded vesicles. Vesicle fusion for $\mathrm{pHrodo-loaded} \mathrm{vesicles} \mathrm{was} \mathrm{defined}$ as an abrupt decline in peak fluorescence intensity exceeding $60 \%$ within two frames (83 ms) with a total decrease of $>90 \%$ relative to baseline fluorescence (filled circles, $\boldsymbol{B}$ ). A few pHrodoloaded vesicles (14\%; 5 of 36) exhibited more delayed fluorescence declines (open circles, $\boldsymbol{B}$ ) and were therefore not defined as fusion events. $\boldsymbol{C}$, The average rate of fluorescence decline for single vesicles loaded with pHrodo (filled circles) was faster than the rise in fluorescence observed as vesicles approached the membrane (filled triangles), advancing deeper into the evanescent field of illumination. This difference was observed even when the few pHrodo-loaded vesicles that exhibited more delayed fluorescence declines (open circles, $\boldsymbol{B}$ ) were included (open squares, $\mathbf{C}$ ). When plotting the rate of fluorescence increase, the timescale was reversed (top ordinate) to facilitate comparison with rates of fluorescence decline. the terminal cytoplasm rather than those at the membrane surface. After loading a large number of vesicles by incubating darkadapted retinas with $\mathrm{pHrodo}$ for $30 \mathrm{~min}$, we stimulated release by bath application of $50 \mathrm{~mm} \mathrm{KCl}$ and observed a pronounced decline in intraterminal fluorescence. The decline observed by epifluorescence cannot be explained simply by increased vesicle mobility, suggesting instead that pHrodo was emptied from synaptic vesicles by fusion ( $n=9$; data not shown).

Protons can be released from synaptic vesicles in cone terminals within $1 \mathrm{~ms}$ (DeVries, 2001). The finding that pHrodo fluorescence declined more slowly $(60-100 \%$ decline in $83 \mathrm{~ms})$ cannot therefore be explained simply by loss of protons. Furthermore, pHrodo fluorescence is not fully quenched at the extracellular $\mathrm{pH}$ of 7.8. As an additional test of whether the decline in pHrodo fluorescence involved emptying of dye from the vesicle lumen, we loaded vesicles with $10 \mathrm{kDa}$ dextran-conjugated tetramethylrhodamine (Invitrogen), which is not strongly $\mathrm{pH}$ sensitive. Like pHrodo, depolarization with $50 \mathrm{~mm} \mathrm{KCl}$ triggered the rapid and complete disappearance of tetramethylrhodamineloaded vesicles in six rods (data not shown).

Although we used light polarized parallel to the plane of incidence to optimize detection of FM1-43 spreading in the membrane (Sund et al., 1999), we did not observe clouds of fluorescence spreading laterally in the plasma membrane away from sites of fusion, in contrast with studies in retinal bipolar and neuroendocrine cells (Steyer et al. 1997; Zenisek et al., 2000, 2002). We tried a number of different approaches to look for dye spread and fluorescence clouds. (1) Clouds were not revealed by averaging images collected from 32 individual events, aligned at their peak fluorescence intensities. (2) Fluorescent clouds were not observed in rods loaded by puff application of FM1-43 (10 $\mu \mathrm{M})$ coapplied with $25 \mathrm{~mm} \mathrm{KCl}$ for $10 \mathrm{~s}$, similar to loading protocols used with bipolar cells (Zenisek et al., 2000, 2002). (3) Clouds were not observed with release events after washing with Advasep-7 $(500 \mu \mathrm{M})$ to remove residual FM1-43 from the plasma membrane. We did not routinely use Advasep-7 because cells were less healthy after treatment. (4) Plating rods on uncoated glass rather than Cell Tak-coated coverslips did not reveal clouds of FM1-43 fluorescence. (5) To enhance dye retention in the membrane and thus increase the likelihood of detecting lateral spread of the dye, we examined vesicles loaded with FM1-84 (10 $\mu \mathrm{M}$ for $1 \mathrm{~min}$ ), a styryl dye with slower $K_{\text {off }}$ than FM1-43 (Wu et al., 2009), but did not see clouds with this dye. Two explanations for the inability to observe lateral dye spread seem particularly plausible. (1) Rod terminals made contact with glass coverslips in very limited areas and exhibited inhomogeneities in fluorescence intensity (e.g., the dark spot near the center of the terminal in Fig. 1D), suggesting uneven attachment to the glass or regional differences in membrane composition that might impede the detection of lateral dye spread. (2) Release from rods normally occurs within synaptic invaginations in the terminal. If synaptic invaginations remain even partially intact in isolated cells, then the plasma membrane near release sites may not lie entirely parallel to the surface of the coverslip.

Typically, very few vesicles were observed to be immobilized at or near the membrane surface before depolarizing stimulation in either FM1-43-loaded ( $0.11 \pm 0.07$ vesicles/terminal, $n=19$ terminals $)$ or pHrodo-loaded $(0.13 \pm 0.06$ vesicles/terminal, $n=$ 30 terminals) rod terminals. Although rods normally lost their light-sensitive outer segments during the isolation procedure, the zero current potential attained during voltage ramps indicated a resting membrane potential in isolated rods of $-37.3 \pm 6.7 \mathrm{mV}$ $(n=9)$, similar to the resting membrane potential of intact rods 

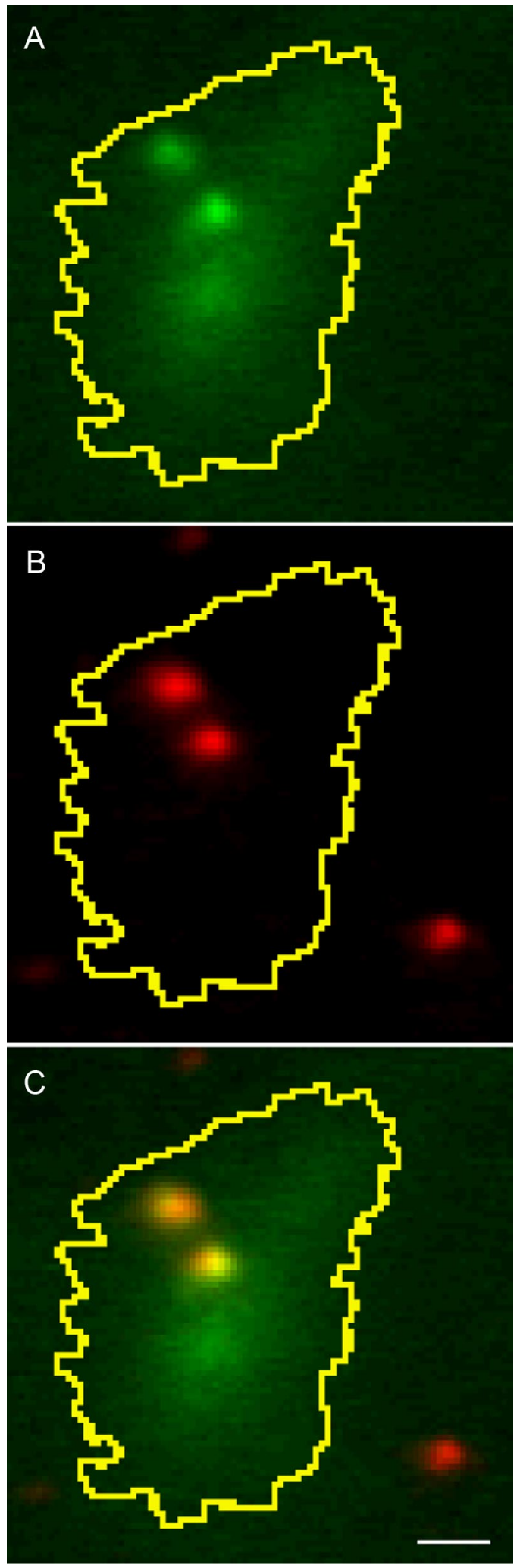

Figure 4. Simultaneous incubation with both FM1-43 and pHrodo loaded the same organelles. For this experiment, vesicle release was inhibited by use of $1 \mathrm{~mm} \mathrm{Co}{ }^{2+}$ in nominally $\mathrm{Ca}^{2+}$-free medium. $\boldsymbol{A}, \mathrm{FM1}-43$-loaded organelles illuminated by $488 \mathrm{~nm}$ laser. $\boldsymbol{B}$, pHrodoloaded organelles illuminated with $561 \mathrm{~nm}$ laser. C, Overlaid image shows colocalization of both fluorescent labels in the same presumptive synaptic vesicles. Scale bar, $1 \mu \mathrm{m}$.

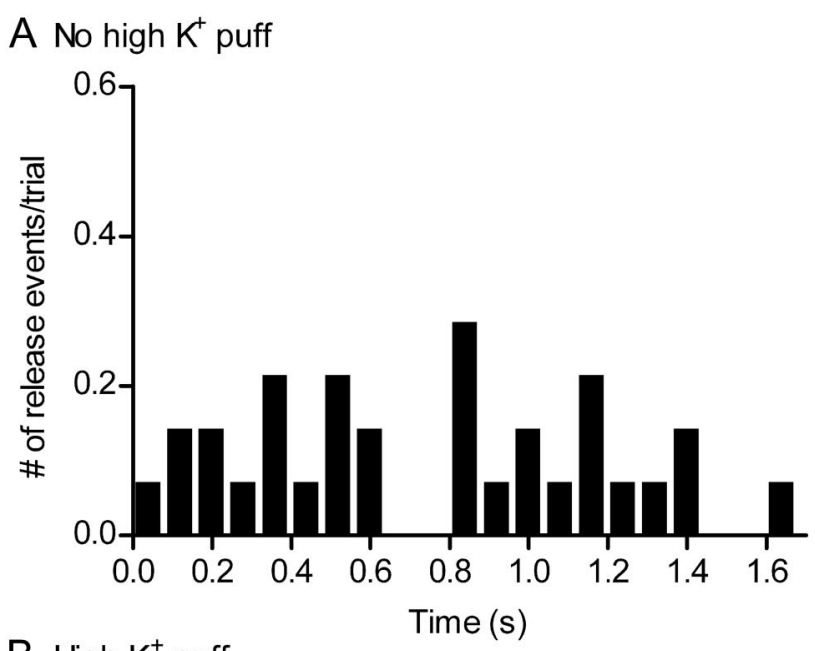

B High $\mathrm{K}^{+}$puff

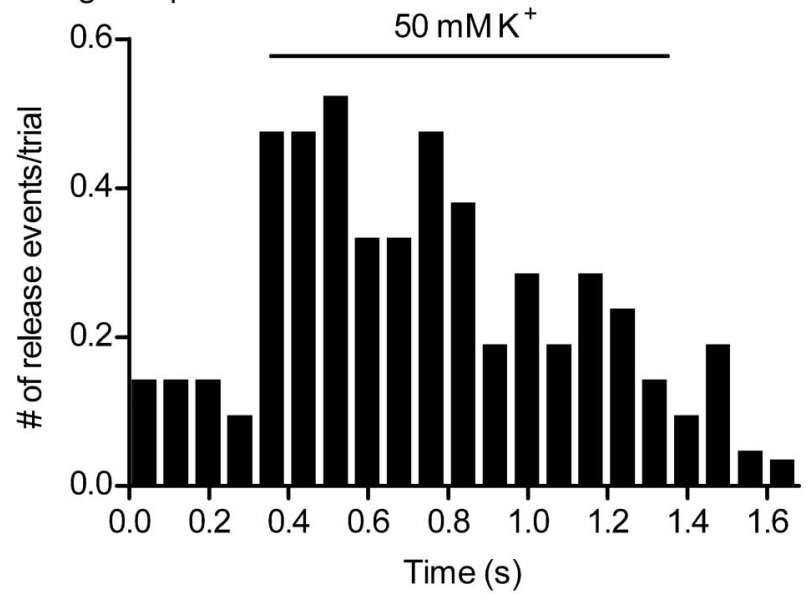

C High $\mathrm{K}^{+}$puff $+1 \mathrm{mM} \mathrm{Co}^{2+}$

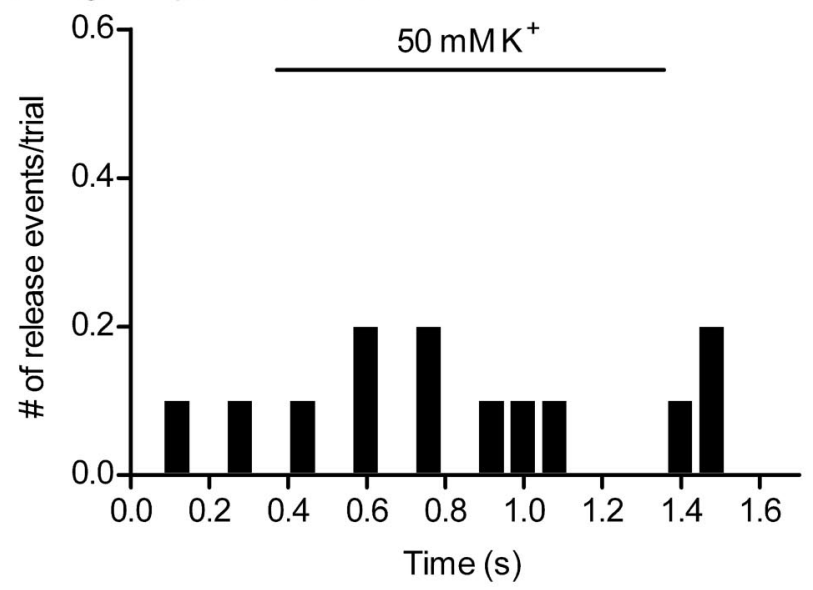

Figure 5. Depolarization-evoked disappearance of fluorescent organelles was blocked by a $\mathrm{Ca}^{2+}$ channel blocker, $\mathrm{Co}^{2+}$. Rod terminals loaded with dextran-conjugated pHrodo were depolarized by puff application of $50 \mathrm{~mm} \mathrm{KCl}$. The number of release events per rod terminal per trial was binned in $80 \mathrm{~ms}$ increments. $A$, Release from unstimulated rod terminals without $\mathrm{KCl}$ puff ( $n=8$ rods). $\boldsymbol{B}$, Release from rod terminals stimulated by $50 \mathrm{~mm} \mathrm{KCl} \mathrm{puff} \mathrm{(} n=15 \mathrm{rods})$. $\boldsymbol{C}$, Release from rods stimulated by $\mathrm{KCl}$ puff in the presence of $1 \mathrm{~mm} \mathrm{Co}^{2+}$ and nominally $\mathrm{Ca}^{2+}$ free medium ( $n=6$ rods).

in darkness. Because of the high sensitivity of the release mechanism in rods to low levels of intracellular $\mathrm{Ca}^{2+}$ (Rieke and Schwartz, 1996; Thoreson et al., 2004; Sheng et al., 2007), we hypothesized that resting submembrane $\left[\mathrm{Ca}^{2+}\right]$ at these rela- 

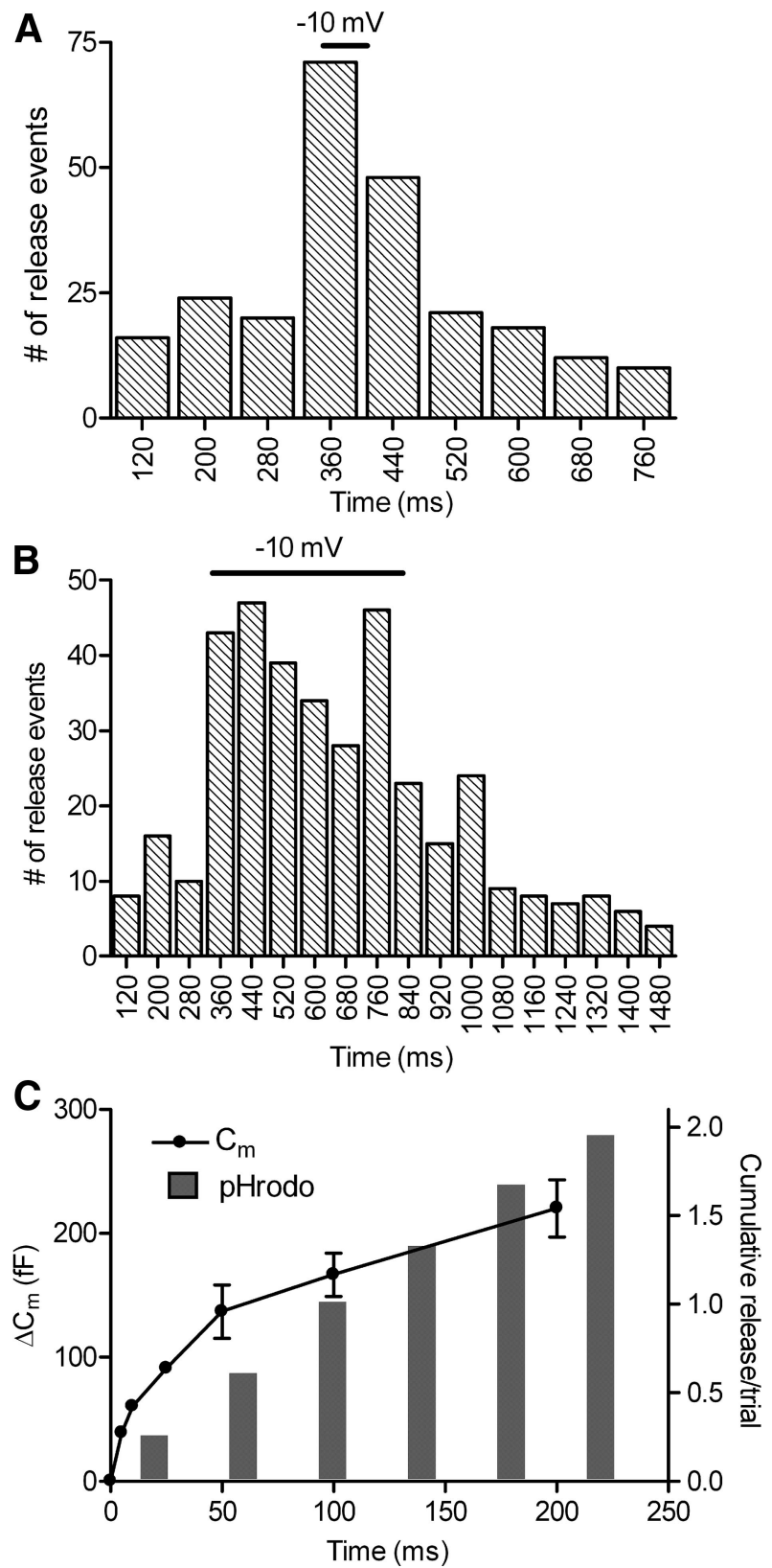

Figure 6. Kinetics of exocytosis measured optically was similar to that measured by electrophysiological techniques. Rods loaded with dextran-conjugated pHrodo were depolarized from -70 to $-10 \mathrm{mV}$ for $50 \mathrm{~ms}(\boldsymbol{A})$ or $500 \mathrm{~ms}(\boldsymbol{B})$. The timing of the TTL trigger pulse sent from the imaging computer jittered between two frames, occurring during images acquired either 330 or $370 \mathrm{~ms}$ into the trial. To accommodate this frame-to-frame jitter, the number of release events was binned in $80 \mathrm{~ms}$ increments. The rate of release rose and declined rapidly during the $50 \mathrm{~ms}$ test step ( $\boldsymbol{A} ; n=70$ trials in 32 rods). Release also increased rapidly with the $500 \mathrm{~ms}$ test step and declined after the end of the step ( $\boldsymbol{B} ; n=55$ trials in 20 rods). $\boldsymbol{C}$, A comparison of the cumulative increase in fusion events measured optically with cumulative fusion measured electrophysiologically from changes in rod membrane capacitance. Membrane capacitance increases were evoked by depolarizing test steps to $-10 \mathrm{mV}$ for durations of $5,10,25,50,100$, and $200 \mathrm{~ms}$ applied to rods in a retinal slice preparation ( $n=7$, circles). The amplitude of the capacitance jump was measured over a $5 \mathrm{~ms}$ window beginning $30 \mathrm{~ms}$ after termination of the test step. For optical measurements of release, the cumulative histogram of release events evoked by $500 \mathrm{~ms}$ test steps to $-10 \mathrm{mV}$ (data in $\boldsymbol{B}$ ) was binned at $40 \mathrm{~ms}$ intervals (bars).

tively depolarized membrane potentials (Szikra and Krizaj, 2006) might be capable of sustaining tonic release and thereby deplete vesicles from membrane docking sites. In support of the hypothesis that rod release sites were depleted of vesicles at the resting
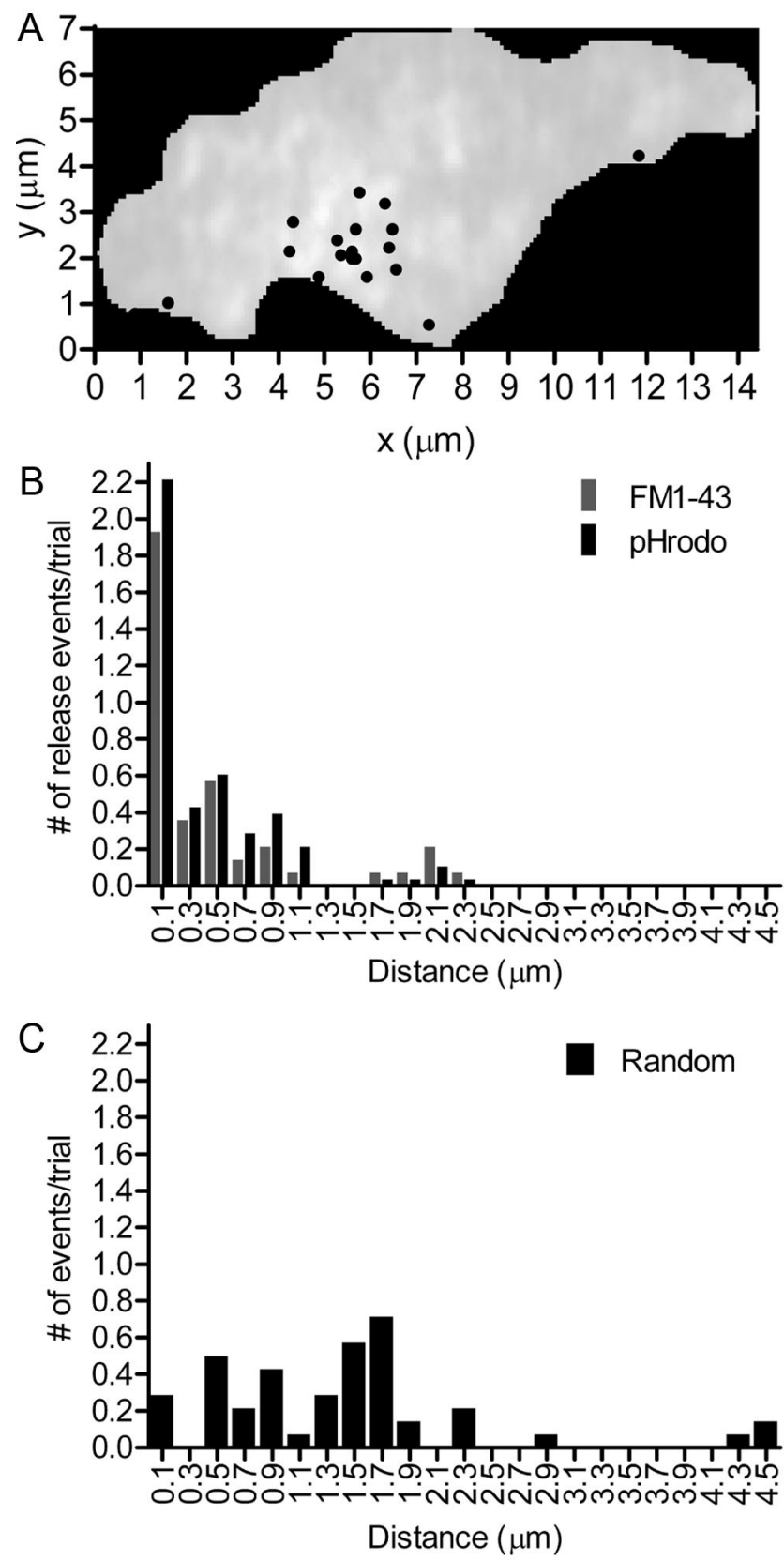

Figure 7. Stimulus-triggered release events clustered close to one another in rod terminals. $A$, Illustration of the spatial distribution of individual release events evoked by two $500 \mathrm{~ms}$ depolarizing steps $(-70$ to $-10 \mathrm{mV})$ applied to a rod terminal loaded with pHrodo. $\boldsymbol{B}$, Histogram of the distances from the nearest neighboring release event for release events triggered by $50 \mathrm{~mm} \mathrm{KCl}$ puff application after brief incubation of rods with either FM1- 43 (black bars; $n=$ 14 puffs in 9 rods) or pHrodo (gray bars; $n=28$ puffs in 14 rods). C, Histogram of distance from the nearest neighboring events for simulated random events. The $x$ and $y$ coordinates for random events were generated using a random-number generator and superimposed onto the footprints of FM1-43-loaded cells ( $n=9$ cells).

membrane potential in isolated rods, more vesicles were immobilized near the membrane surface when $\mathrm{Ca}^{2+}$ entry into pHrodo-loaded cells was inhibited by application of $1 \mathrm{~mm} \mathrm{Co}^{2+}$ in nominally $\mathrm{Ca}^{2+}$-free Ringer's solution $(2.3 \pm 0.4$ vesicles/ terminal, $n=7$ terminals; Fig. 4 ) or by voltage clamping rods at $-70 \mathrm{mV}$ ( $1.9 \pm 0.5$ vesicles/terminal, $n=9$ terminals $)$.

Although the ability of FM1-43 to label synaptic vesicles is well established (Betz and Bewick, 1992; Cochilla et al., 1999; Rea et al., 2004), dextran-conjugated pHrodo has not to our knowl- 

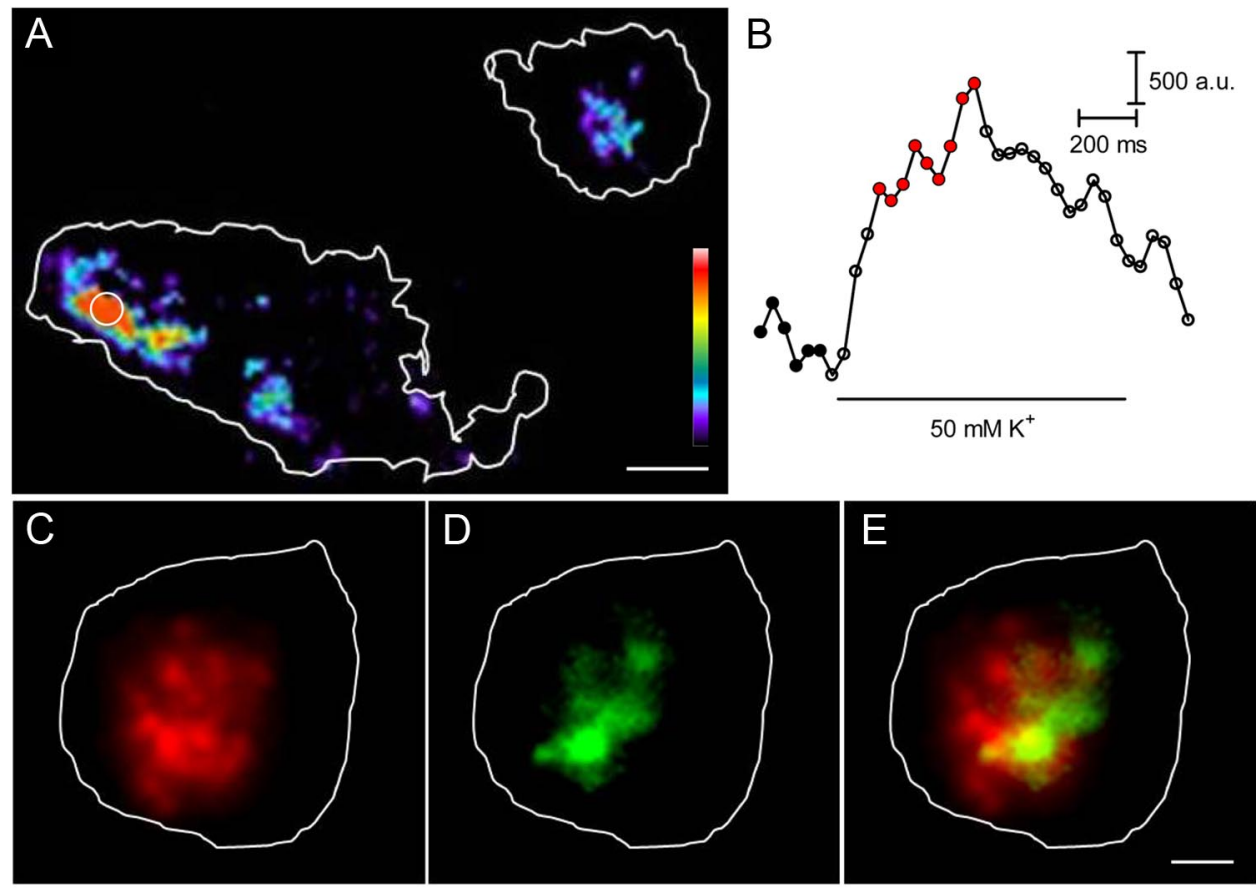

Figure 8. Release sites cluster close to the ribbon. To observe release of a large number of vesicles, rods were incubated with pHrodo for 30 min. Release was then stimulated by puff application of $50 \mathrm{~mm} \mathrm{KCl}$ for $1 \mathrm{~s}$. $\boldsymbol{A}$, Vesicle recruitment map generated by subtracting the average of six images before the puff (filled black circles in $\boldsymbol{B}$ ) from the average of nine images (red circles in $\boldsymbol{B}$ ) during the puff. The two terminal footprints of a rod attached to the coverslip are outlined in white. $\boldsymbol{B}$, Time course of fluorescence changes measured in a region of interest placed over the area with the largest fluorescence change (white circle). C, Vesicle recruitment map of a rod terminal loaded with pHrodo by 30 min incubation. The rod was voltage clamped and stimulated by sustained depolarization to $-15 \mathrm{mV}$. The vesicle recruitment map was generated by subtracting the average of seven images before stimulation from the average of 19 images obtained during stimulation. D, Ribbons were labeled by introducing a HyLite488-conjugated, high-affinity Ribeye-binding peptide ( $250 \mathrm{~nm}$ ) through the patch pipette and visualized by using a $488 \mathrm{~nm}$ laser angled to produce epifluorescent illumination. $\boldsymbol{E}, 0$ verlay of images in $\boldsymbol{C}$ and $\boldsymbol{D}$. Scale bar, $1 \mu \mathrm{m}$.

edge been used previously to visualize synaptic vesicle exocytosis. We therefore tested whether pHrodo labeled the same organelles as FM1-43 by loading rods simultaneously with both dyes. When cells were superfused with $1 \mathrm{mM} \mathrm{Co}^{2+}$ in a nominally $\mathrm{Ca}^{2+}$-free Ringer's solution to promote the retention of vesicles at or near the membrane surface, we observed that presumptive synaptic vesicles loaded with FM1-43 were also labeled with pHrodo (Fig. 4).

As expected for $\mathrm{Ca}^{2+}$-dependent exocytosis, disappearance of pHrodo-loaded vesicles was stimulated by depolarization and blocked by inhibiting $\mathrm{Ca}^{2+}$ entry. Figure $5 A$ shows a histogram of putative release events in pHrodo-loaded rod terminals in the absence of stimulation ( $n=8$ rods). The timing of fusion for each event was defined as the beginning of the fluorescence decline. Figure $5 B$ shows that depolarization by puff application of $50 \mathrm{~mm}$ $\mathrm{KCl}$ stimulated a large increase in disappearance events $(n=15$ rods). This depolarization-evoked increase in release was blocked in the presence of $1 \mathrm{mM} \mathrm{Co}^{2+}$ and nominally $\mathrm{Ca}^{2+}$-free solution (Fig. $5 C, n=6$ rods). The $\mathrm{KCl}$-evoked increase in release was also blocked by bath application of $\mathrm{Cd}^{2+}(0.1 \mathrm{~mm}, n=17$ rods; data not shown).

The rate at which vesicles disappear from unstimulated terminals (1.3 vesicles/s; Fig. $5 A$ ) depends in part on the number of vesicles that were labeled by the dye. Given estimated tonic release rates of 127-400 vesicles/s in rods (Rieke and Schwartz, 1996; Sheng et al., 2007), an average spontaneous rate of $\sim 1.3$ vesicles/s involving membrane footprints containing $36 \%$ of the release sites in the terminal is consistent with loading of $\sim 1-3 \%$ of the vesicle pool. Even in the presence of $\mathrm{Ca}^{2+}$ channel blockers, we observed slow tonic disappearance of vesicles at a rate of 0.8 vesicles/s. This rate might be even lower except that the pres- ence of $\mathrm{Ca}^{2+}$ channel blockers probably increased the retention of dye-loaded vesicles in these experiments. Disappearance events observed in the presence of $\mathrm{Ca}^{2+}$ channel blockers may represent spontaneous $\mathrm{Ca}^{2+}$-independent fusion but might also be caused by dye-loaded organelles retreating away from the evanescent field. To minimize the contribution of occasional spontaneous events to the analysis, we confined analysis of the properties of release to events that occurred during depolarizing stimulation.

As another test of whether the disappearance of pHrodoloaded spots represented vesicle fusion, we stimulated voltageclamped rods with depolarizing test steps $(-70$ to $-10 \mathrm{mV})$ to activate L-type $\mathrm{Ca}^{2+}$ channels and thereby trigger release. To accommodate a small frame-to-frame jitter in the timing of the TTL trigger output from the imaging computer (see Materials and Methods), optical measurements of release events using pHrodo were binned in $80 \mathrm{~ms}$ intervals to encompass two frames. Figure $6 \mathrm{~A}$ shows that release rose immediately during stimulation with a brief 50 ms test step ( $n=25$ rods) and declined rapidly afterward. With a longer test step (500 ms; $n=20$ rods), release rose quickly at the beginning of the step and declined a bit more slowly (Fig. 6B). This slow decline may reflect maintained elevation of intraterminal $\left[\mathrm{Ca}^{2+}\right]$ after the step involving CICR (Cadetti et al., 2006). Simultaneous whole-cell recordings from rods and postsynaptic horizontal or OFF bipolar cells showed that, when cyclothiazide is used to block glutamate receptor desensitization, postsynaptic currents persisted for $>100 \mathrm{~ms}$ after termination of a 500 ms test step (Rabl et al., 2005; W.B.T., unpublished observations).

We compared the cumulative increase in the number of fusion events measured optically with cumulative fusion measured 

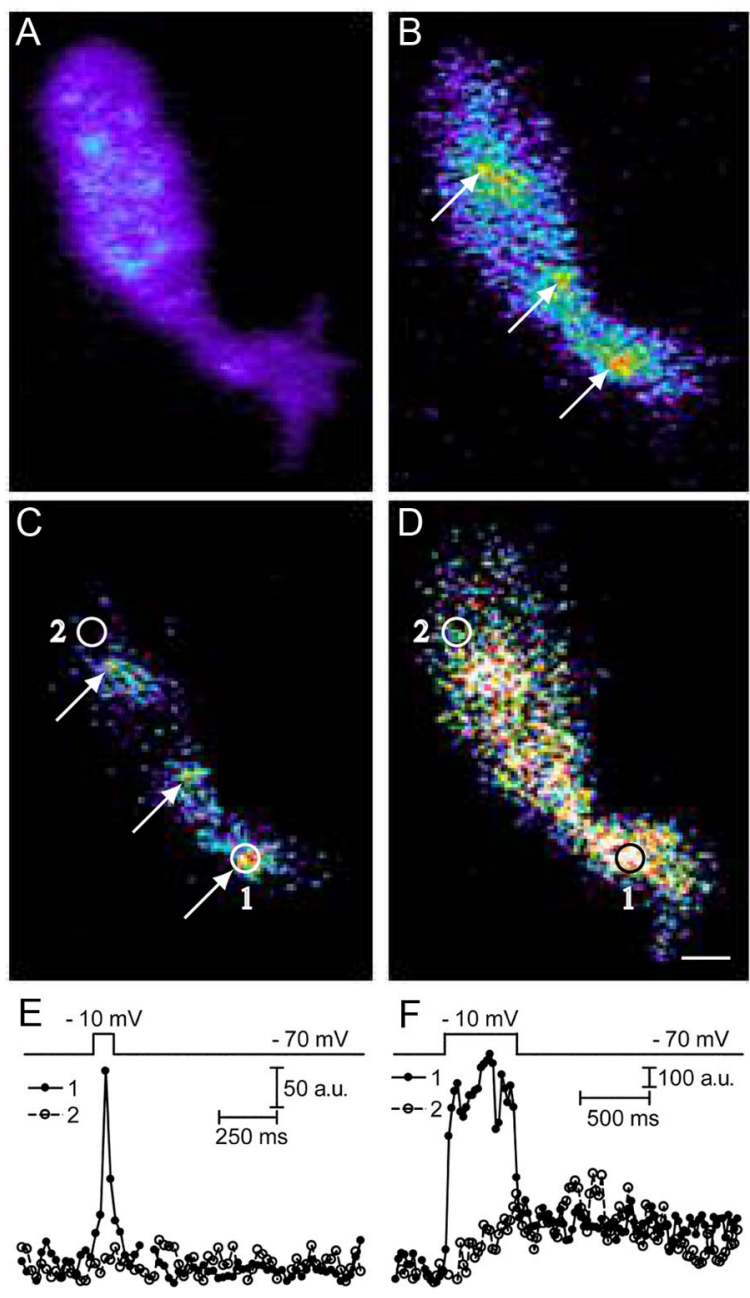

F $-10 \mathrm{mV}$

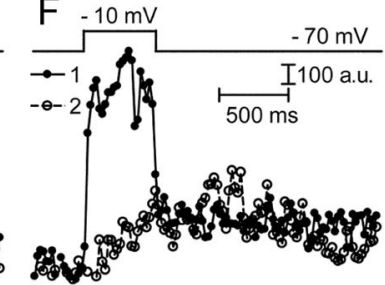

G

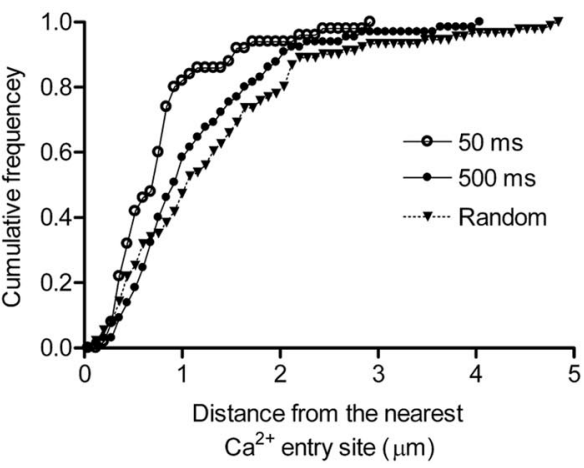

Figure 9. Long depolarizing steps triggered a spread of $\mathrm{Ca}^{2+}$ through the terminal and increased release farther away from ribbons. Synaptic vesicles were loaded with dextranconjugated pHrodo, and then rods were voltage clamped to introduce Flu0 $5 \mathrm{~F}(100 \mu \mathrm{m})$ through the patch pipette. Voltage-clamped rods were stimulated with $50 \mathrm{~ms}(\boldsymbol{A}-\boldsymbol{C})$ or $500 \mathrm{~ms}$ (D) steps from -70 to $-10 \mathrm{mV}$. Changes in $\left[\mathrm{Ca}^{2+}\right]$ were monitored with TIRFM using a $488 \mathrm{~nm}$ laser. The difference image $(C)$ was generated by subtracting the average of 39 control images before stimulation $(\boldsymbol{A})$ from the test image obtained during stimulation with a $50 \mathrm{~ms}$ step $(\boldsymbol{B})$. D shows the difference image for Fluo5F fluorescence obtained at the end of a $500 \mathrm{~ms}$ step in the same rod terminal. The fluorescence intensities within regions 1 and 2 were plotted against time for $50 \mathrm{~ms}(\boldsymbol{E})$ and $500 \mathrm{~ms}(\boldsymbol{F})$ steps. In $\boldsymbol{G}$, the relative cumulative frequency of pHrodo release events triggered by $50 \mathrm{~ms}$ (open circles, $n=50$ events from 7 rods) or $500 \mathrm{~ms}$ (filled circles, $n=65$ events from 5 rods) steps were plotted against distance from the nearest $\mathrm{Ca}^{2+}$ entry site. These two distributions differed significantly (Kolmogorov-Smirnov test, $p=0.019$ ). We also plotted the cumulative frequency of simulated fusion events that were distributed randomly throughout the footprint (triangles, $n=91$ events from 7 rods; Kolmogorov-Smirnov test, $p=0.002$ compared with $500 \mathrm{~ms}$ steps). Scale bar, $1 \mu \mathrm{m}$. electrophysiologically from exocytotic increases in rod membrane capacitance (Fig. 6C). Membrane capacitance increases were evoked by depolarizing test steps of increasing duration ( 5 , $10,25,50,100,200 \mathrm{~ms}$ ) applied to intact rods in the retinal slice. Release kinetics measured in these experiments was similar to that of previous studies (Rabl et al., 2005). For optical release measurements, we determined the cumulative increase in fusion events during $500 \mathrm{~ms}$ depolarizing steps binned at $40 \mathrm{~ms}$ intervals (bars). As illustrated in Figure 6C, there was generally good agreement between the kinetics of release measured by optical and electrophysiological techniques. Together, the data in Figures 2-6 indicate that the disappearance of pHrodo-loaded vesicles was primarily attributable to fusion of individual synaptic vesicles.

\section{Vesicles are released primarily at synaptic ribbons but also at} non-ribbon sites

Individual release events evoked by depolarizing stimulation tended to cluster together in rod terminals. This is illustrated in Figure $7 \mathrm{~A}$, which shows a representative map of the location of depolarization-evoked individual release events in a single rod terminal evoked in two trials by depolarizing stimulation with $500 \mathrm{~ms}$ steps to $-10 \mathrm{mV}$. The base of the ribbon terminals is $\sim 1$ $\mu \mathrm{m}$ long in rods (Townes-Anderson et al., 1985), and we found that ribbons labeled by HyLite488-conjugated Ribeye-binding peptide were separated by an average of $2.4 \pm 0.2 \mu \mathrm{m}(n=63)$. Figure $7 B$ shows a histogram of the number of release events (evoked by puff application of $50 \mathrm{~mm} \mathrm{KCl}$ ) as a function of the distance from the center of each fusion event to its nearest neighbor. With both FM1-43 (27 of 52 events in nine rods) and pHrodo (62 of 122 events in 14 rods), $>50 \%$ of release events occurred within $180 \mathrm{~nm}$ of the nearest neighboring fusion event (Fig. 7B). We also simulated randomly distributed events using the same synaptic terminal footprints and numbers of events observed in trials with FM1-43. In contrast with actual release, half of the randomly placed events occurred within $1.4 \mu \mathrm{m}$ of the nearest neighboring event (Fig. $7 C$ ). Thus, release from rods was clustered much more tightly than predicted by a simply random distribution of fusion events.

To examine clustering of release in a larger number of vesicles, we labeled a larger fraction of the vesicle pool by loading photoreceptors with pHrodo for $30 \mathrm{~min}$. In terminals in which a large population of vesicles was loaded, depolarization by puff application of $50 \mathrm{~mm} \mathrm{KCl}$ stimulated a rise in pHrodo fluorescence as vesicles approached the membrane, followed by a slow decline as they fused and emptied their contents (Fig. 8B). As discussed previously, the decline of fluorescence in this large population of vesicles was much slower than the fluorescence declines observed with individual vesicles (Fig. 3). To map the sites in which vesicles were recruited to the membrane, we subtracted the average of six images obtained before stimulation (Fig. $8 B$, filled black circles) from the average of nine images obtained during the depolarization-evoked increase in brightness (Fig. $8 B$, red circles). The resulting difference image shows a highly localized increase in fluorescence reflecting the increase in vesicles awaiting fusion at the membrane clustered in three areas of the two terminals (Fig. 8A). We observed similar clustering of vesicle recruitment sites in all eight rod terminals that we tested in this way.

To test whether these clusters of vesicle recruitment sites were close to synaptic ribbons, we labeled ribbons using a highaffinity, HyLite488-conjugated Ribeye-binding peptide (250 nM; Francis et al., 2011) introduced through a patch pipette. Although ribbons labeled by the Ribeye-binding peptide could not be observed in the thin evanescent field using TIRFM, they could 
A

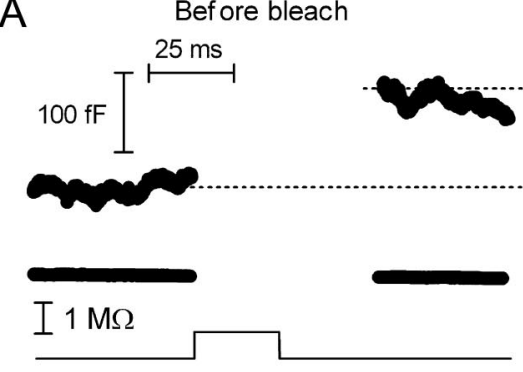

B

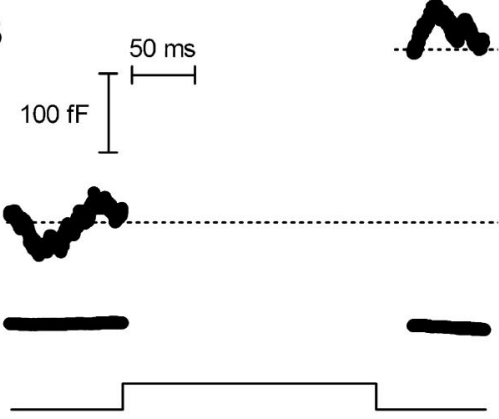

C Ribeye-binding peptide

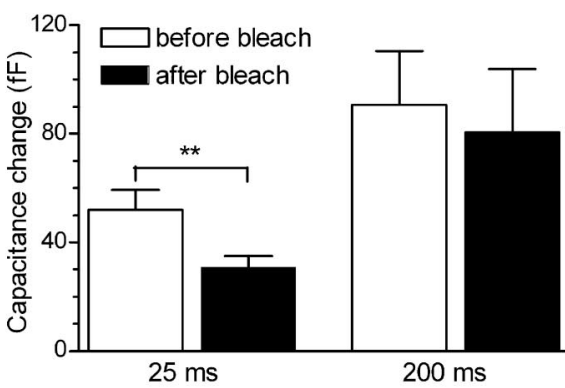

After bleach
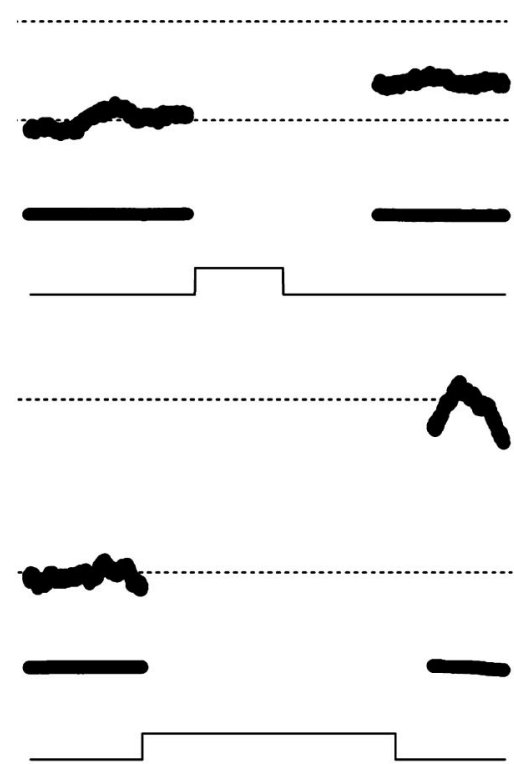

D Scrambled peptide

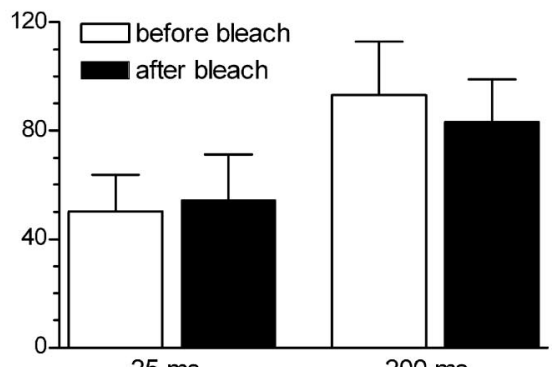

$25 \mathrm{~ms}$

$200 \mathrm{~ms}$

Figure 10. Effects of acute ribbon damage by FALI on rod exocytosis. A rod loaded with fluorescein-conjugated Ribeye-binding peptide $(40 \mu \mathrm{m})$ was bleached with a $488 \mathrm{~nm}$ laser for $1 \mathrm{~min}$. Damaging the ribbon by FALI inhibited the capacitance jump evoked by a 25 ms test step from -70 to $-10 \mathrm{mV}(\boldsymbol{A})$ more strongly than it inhibited the capacitance jump evoked by a $200 \mathrm{~ms}$ step $(\boldsymbol{B})$. Control responses before bleach are averaged from two trials in the same cell. Responses after bleach are averaged from three trials. C, Bar graph showing that capacitance changes evoked by short $25 \mathrm{~ms}$ test steps $(-70$ to $-10 \mathrm{mV}$ ) were significantly inhibited by damaging the ribbon with FALI using the Ribeye-binding peptide $\left(-38.3 \pm 7.5 \%, n=10\right.$; ${ }^{* *}$ paired $t$ test, $\left.p=0.0017\right)$. Damaging the ribbon by FALI caused a smaller percentage inhibition of capacitance jumps evoked by 200 ms steps that did not attain statistical significance $(-8.7 \pm 22.1 \%, n=9$; paired $t$ test, $p=0.43)$. D. Capacitance jumps evoked by 25 or $200 \mathrm{~ms}$ steps were not significantly reduced by FALI with a scrambled control peptide $(25 \mathrm{~ms}, n=7$, paired test, $p=0.76 ; 200 \mathrm{~ms}, n=7, p=$ 0.67). The amplitudes of depolarization-evoked capacitance increases were measured $30 \mathrm{~ms}$ after the end of the test pulse.

be seen by angling the laser more steeply to illuminate the cell more deeply (Fig. 8D). As illustrated in Figure 8, sustained depolarization to $-15 \mathrm{mV}$ in a voltage-clamped rod stimulated increases in pHrodo-fluorescence $(C)$ that were confined primarily to regions close to fluorescently labeled ribbons $(D)$. Although the ribbons were visualized at a slightly deeper plane than vesicles, the merged image (Fig. $8 E$ ) showed that the clusters of vesicles recruited to release sites overlapped closely with ribbons.

$\mathrm{Ca}^{2+}$ channels are concentrated near synaptic ribbons in rods (Nachman-Clewner et al., 1999; Morgans 2001; tom Dieck et al., 2005; Mercer and Thoreson, 2011). Consistent with this, we found that stimulating rods with $50 \mathrm{~ms}$ depolarizing test steps $(-70$ to $-10 \mathrm{mV})$ evoked focal hotspots of $\mathrm{Ca}^{2+}$ entry in rod terminals loaded with the $\mathrm{Ca}^{2+}$ indicator Fluo5F. The number of $\mathrm{Ca}^{2+}$ hot spots per terminal $(2.8 \pm 0.4, n=9)$ was similar to the number of ribbons labeled with a high-affinity Ribeye-binding peptide $(2.3 \pm 0.3, n=31, p=0.42)$. Figure $9 A$ shows a rod terminal loaded with Fluo5F before stimulation. Application of the $50 \mathrm{~ms}$ depolarizing test step stimulated focal $\mathrm{Ca}^{2+}$ entry at three sites in this terminal (Fig. 9B, arrows). These focal $\mathrm{Ca}^{2+}$ entry sites can also be seen in the difference image in Figure $9 C$. The time course for $\mathrm{Ca}^{2+}$ changes in two regions of interest, one placed over a focal $\mathrm{Ca}^{2+}$ entry site (region 1) and another placed some distance from focal $\mathrm{Ca}^{2+}$ entry sites (region 2), are shown in Figure $9 E$ for a $50 \mathrm{~ms}$ step and Figure $9 F$ for a $500 \mathrm{~ms}$ step. Depolarization with a 50 ms step evoked a localized $\mathrm{Ca}^{2+}$ increase in region 1 near the presumed location of a ribbon but no change in region 2 . In contrast, depolarization with a $500 \mathrm{~ms}$ step stimulated spread of $\mathrm{Ca}^{2+}$ throughout the terminal, elevating $\mathrm{Ca}^{2+}$ in both regions 1 and 2. The spread of $\mathrm{Ca}^{2+}$ triggered by long depolarizing test steps (to $-10 \mathrm{mV}$ for $\geq 200 \mathrm{~ms}$ ) in rod terminals has been shown to involve CICR (Krizaj et al., 1999; Cadetti et al., 2006; Suryanarayanan and Slaughter, 2006; Babai et al., 2010).

Because ribbons could not be observed directly by TIRFM, we used sites of focal $\mathrm{Ca}^{2+}$ entry evoked by $50 \mathrm{~ms}$ depolarizing test steps as indicators for ribbon location. Most release events triggered by $50 \mathrm{~ms}$ steps occurred within $1 \mu \mathrm{m}$ of the nearest $\mathrm{Ca}^{2+}$ entry site, suggesting that most release occurs close to ribbons. However, vesicles were also released farther away from ribbons (Fig. 9G). With $50 \mathrm{~ms}$ test steps, $18 \%$ of release events ( 9 of 50 ) occurred $>1.0 \mu \mathrm{m}$ from the nearest $\mathrm{Ca}^{2+}$ entry site. Application of longer test steps (500 ms) stimulated spread of $\mathrm{Ca}^{2+}$ throughout the terminal (Fig. 9D) and enhanced release far from the ribbon, with $45 \%$ of release events ( 29 of 65 ) occurring $>1.0 \mu \mathrm{m}$ from the nearest $\mathrm{Ca}^{2+}$ entry site. The cumulative histogram in Figure $9 G$ shows that release events triggered by $50 \mathrm{~ms}$ steps (open circles; mean of $0.80 \pm 0.08 \mu \mathrm{m}, n=50$ release events from 7 rods) occurred closer to $\mathrm{Ca}^{2+}$ entry sites than 500 ms steps (filled circles; mean of $1.15 \pm 0.10 \mu \mathrm{m}, n=65$ release events from 5 rods; Kolmogorov-Smirnov test comparing cumulative frequency curves, $p=0.019$ ). Simulating a random distribution of vesicle fusion events throughout the footprints yielded a significantly greater distance from the nearest $\mathrm{Ca}^{2+}$ entry site than actual fusion evoked by 500 ms steps (Fig. 9G, triangles; mean of $1.33 \pm 0.11 \mu \mathrm{m}, n=91$ events from 7 rods; Kolmogorov-Smirnov test, $p=0.002$ ). Thus, $500 \mathrm{~ms}$ steps stimulated greater non-ribbon release than $50 \mathrm{~ms}$ steps but less nonribbon release than predicted by a purely random distribution.

To further analyze which kinetic components of release involve the ribbon, we measured release from voltage-clamped rods and used FALI (Hoffman-Kim et al., 2007) to selectively damage the ribbon by targeting it with a fluorescein-conjugated peptide that binds to Ribeye ( $40 \mu \mathrm{M}$; Zenisek et al., 2004; Zenisek, 
2008). We measured the amount of exocytosis from the increase in membrane capacitance evoked by depolarizing test steps applied to rods in a retinal slice preparation. The amount of release evoked by the first stimulus $(25 \mathrm{~ms},-70$ to -10 $\mathrm{mV}$ ) immediately after FALI was diminished only slightly (Snellman et al., 2011), and so we omitted the first post-bleach response from analysis. Comparing subsequent responses to pre-bleach control responses, we found that capacitance increases evoked by $25 \mathrm{~ms}$ test steps ( -70 to $-10 \mathrm{mV})$ were significantly inhibited $(-38.3 \pm 7.5 \%, n=10$; paired $t$ test, $p=$ 0.0017) after damaging the ribbon by FALI (Fig. 10A,C). Partial inhibition of release by FALI is consistent with binding to approximately half of the available binding sites by the Ribeye-binding peptide, which has a $K_{\mathrm{d}}$ of $\sim 30 \mu \mathrm{M}$ (Zenisek et al., 2004; Snellman et al., 2011). Damaging the ribbon by FALI caused a smaller percentage reduction in the capacitance jump evoked by $200 \mathrm{~ms}$ steps $(-8.7 \pm$ $22.1 \%, n=9$; paired $t$ test, $p=0.43$; Fig. $10 \mathrm{~B}, \mathrm{C})$, consistent with the recruitment of additional non-ribbon release sites with more sustained stimulation. FALI with a scrambled version of the fluoresceinconjugated peptide did not significantly alter capacitance responses to either 25 or 200 ms steps (Fig. 10D). These data are consistent with the imaging results suggesting that the initial fast component of release involves the ribbon and that additional non-ribbon release sites are recruited during sustained depolarization.

\section{Vesicle approach to the membrane}

During depolarizing stimulation with high $\left[\mathrm{K}^{+}\right]$puffs or depolarizing steps, vesicles approached the membrane and remained visible for a short time before disappearing (Fig. 11A). To calculate the velocity of vesicle approach, we converted the increase in vesicle fluorescence to distance ( $z$; Fig. $11 B$ ) by assuming that the evanescent field intensity declined exponentially with length constants $(d)$ of $64 \mathrm{~nm}$ for the $561 \mathrm{~nm}$ laser used for exciting pHrodo or $57 \mathrm{~nm}$ for the $488 \mathrm{~nm}$ laser used for exciting FM1-43:

$$
z=-d \times \ln (I(z) / I(0)) .
$$

$I(z)$ is the average fluorescence intensity within a region of interest enclosing the bright spot, and $I(0)$ is the maximum fluorescence intensity attained by the vesicle just before fusion (Axelrod, 2001). The linear slope of the resulting relationship between vesicle distance and approach time (Fig. 11C) yielded similar approach velocities for vesicles loaded with pHrodo $(843 \pm 65$ $\mathrm{nm} / \mathrm{s}, n=14$ vesicles $)$ or FM1-43 (688 $\pm 74 \mathrm{~nm} / \mathrm{s}, n=10$ vesicles, $p=0.13$ ). These values are similar to the approach velocity found for FM1-43-loaded synaptic vesicles in bipolar cells (Zenisek et al., 2000). Using sites of focal $\mathrm{Ca}^{2+}$ entry as indicators of ribbon location and $50 \mathrm{~ms}$ steps to evoke release, we found no difference in the approach velocity for pHrodo-loaded vesicles that fused within $0.5 \mu \mathrm{m}$ of the nearest focal site of $\mathrm{Ca}^{2+}$ entry $(857 \pm 86 \mathrm{~nm} / \mathrm{s}, n=7$ vesicles $)$ or those that fused $>1.0 \mu \mathrm{m}$ from focal sites of $\mathrm{Ca}^{2+}$ entry $(828 \pm 104 \mathrm{~nm} / \mathrm{s}, n=7$ vesicles, $p=$ 0.84 ). It is worth noting that these velocity measurements were unlikely to report movement on the ribbon itself because fluorescently labeled ribbons were not visible in TIRFM.

As presented previously, vesicles sometimes remained immobilized at or near the membrane for long periods when $\mathrm{Ca}^{2+}$ entry was inhibited. In rods voltage clamped at $-70 \mathrm{mV}$ and loaded with pHrodo, previously immobilized vesicles showed a small fluorescence increase just before their stimulation-evoked disappearance. Figure $12 \mathrm{~A}$ shows an example of the fluorescence changes accompanying fusion of a previously immobilized vesicle. The time course of fluorescence changes in this experiment is plotted in Figure $12 B$ with the corresponding images indicated by letters adjacent to the open circles. The fluorescence intensities averaged from five release events in three rods are plotted against time in Figure $12 C$. These data were normalized to the peak intensity values for each vesicle. Because pHrodo is not inserted into the membrane, this brightening was not caused by changes 

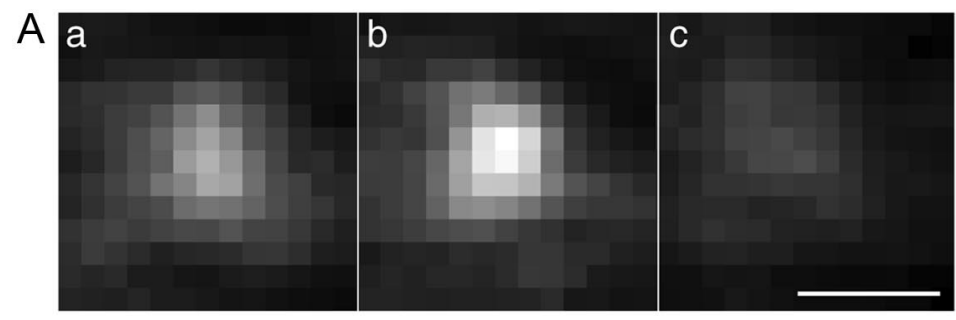

B

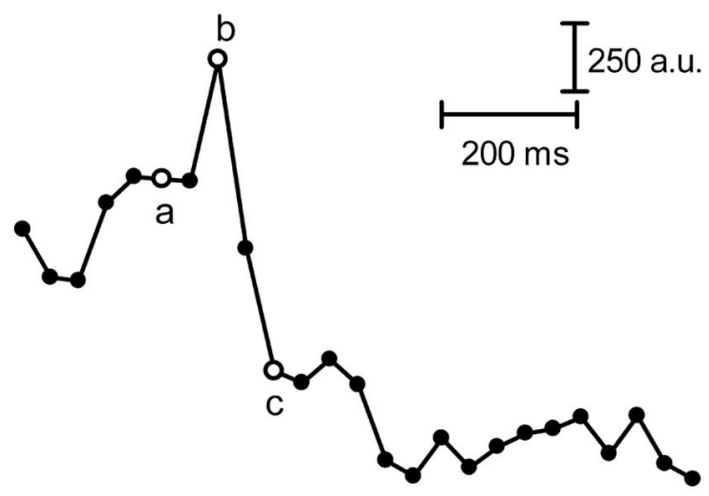

C

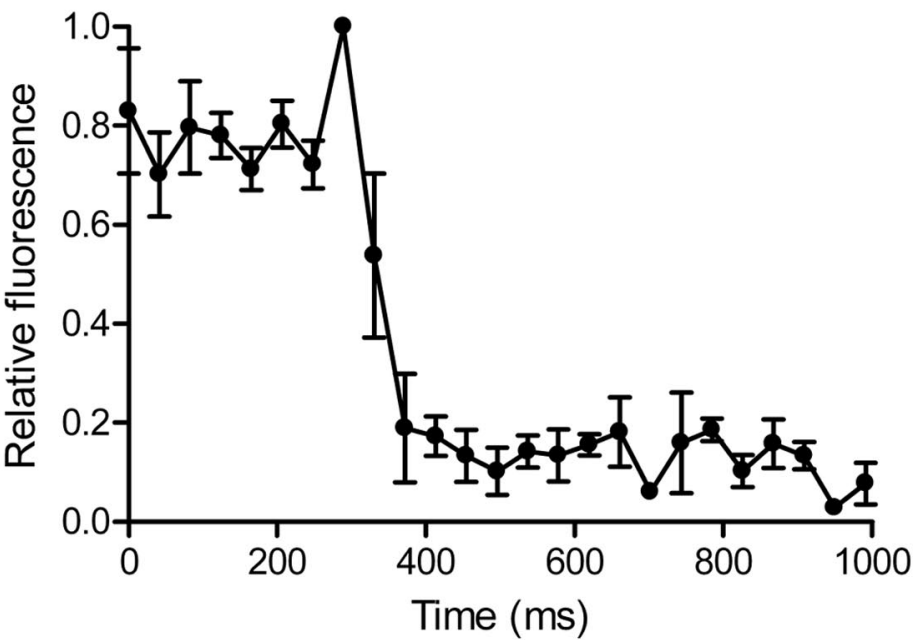

Figure 12. Previously immobilized vesicles advanced a short distance toward the membrane just before fusion. $\boldsymbol{A}$, In a rod that was voltage clamped at $-70 \mathrm{mV}$ and then depolarized to $-10 \mathrm{mV}$, a previously immobilized vesicle (a) loaded with dextranconjugated pHrodo showed a small brightening $(\boldsymbol{b})$ just before fusion $(\boldsymbol{c})$ in response to a depolarizing stimulation. $\boldsymbol{B}$, Fluorescence intensities were plotted against time for the vesicle shown in $\boldsymbol{A}$. Images in $\boldsymbol{A}$ were obtained at the time points marked $\boldsymbol{a}-\boldsymbol{c}$. $\boldsymbol{C}$, Relative fluorescence profiles averaged from five vesicles in three rods and normalized to their peak intensity values. Scale bar, $0.5 \mu \mathrm{m}$.

in the orientation of dye molecules in the vesicle membrane relative to the plane of polarized light but was instead more likely attributable to advance of vesicles deeper into the evanescent field as they approached the plasma membrane (Sund et al., 1999; Zenisek et al., 2002). The vertical distance ( $z$ ) that vesicles moved just before fusion was calculated by assuming that the evanescent field intensity declined exponentially with a length constant of 64 $\mathrm{nm}$ using Equation 3. The transient increase in brightening relative to the fluorescence averaged over the preceding five frames suggests that vesicles advanced $18 \pm 3 \mathrm{~nm}$ closer to the surface of the glass during the final steps of fusion.

\section{Discussion}

Vesicle release properties

The small size, rapid rate of disappearance, calcium dependence, and similarity to electrophysiological release kinetics all indicate that depolarization-evoked disappearance of organelles loaded by brief incubation with FM1-43 or dextran-conjugated pHrodo represented fusion of individual synaptic vesicles. Although FM1-43 can potentially exit vesicles through fusion pores created during kiss-and-run fusion, this appears to occur much more slowly (Wu et al., 2011) than rates of fluorescence decline observed with synaptic vesicles in rods, suggesting that most fusion events involved full collapse (Richards et al., 2005; Serulle et al., 2007). In addition, $10 \mathrm{kDa}$ dextranconjugated dyes $(\sim 3.7 \mathrm{~nm}$ diameter; Leduc et al., 2009) are likely to be too large to permeate fusion pores $(\sim 2.3 \mathrm{~nm}$ diameter; He et al., 2006), and vesicle alkalinization alone does not completely abolish pHrodo fluorescence. Exit of protons through a fusion pore also cannot explain reductions in the fluorescence of $\mathrm{pH}$-insensitive tetramethylrhodamine. Therefore, the depolarization-evoked disappearance of vesicles was most likely attributable to full-collapse fusion.

Newly arriving vesicles advanced the final $\sim 100 \mathrm{~nm}$ toward the membrane at $\sim 800 \mathrm{~nm} / \mathrm{s}$, similar to membrane approach velocity found for synaptic vesicles in bipolar cell terminals (Zenisek et al., 2000). In contrast with conventional synapses, most vesicles in ribbon synapses are freely mobile (Holt et al., 2004; Rea et al., 2004). Assuming $\chi^{2}=2 \mathrm{Dt}$, the diffusion coefficients $(D)$ of 0.11 and $0.015 \mu \mathrm{m}^{2} / \mathrm{s}$ for vesicles in cones (Rea et al., 2004) and bipolar cells (Holt et al., 2004) predict that they should diffuse $100 \mathrm{~nm}$ within 46 and $333 \mathrm{~ms}$, yielding velocities of 2200 and 300 $\mathrm{nm} / \mathrm{s}$, respectively. During release evoked by brief $50 \mathrm{~ms}$ test steps, vesicle approach velocities were similar at ribbon and nonribbon sites. Because $\left[\mathrm{Ca}^{2+}\right]_{\mathrm{i}}$ attains high levels near the ribbon during 50 ms steps, this is consistent with findings that elevation of $\left[\mathrm{Ca}^{2+}\right]_{\mathrm{i}}$ does not increase vesicle mobility at ribbon synapses (Holt et al., 2004; Rea et al., 2004) or neuromuscular junctions (Gaffield and Betz, 2007). However, $\mathrm{Ca}^{2+}$ does increase vesicle approach velocity in brain synaptosomes (Serulle et al., 2007). Our results do not necessarily conflict with evidence that cone ribbons may slow vesicle delivery (Jackman et al., 2009) because we could not directly observe vesicle movement on ribbons that sit outside the evanescent field of illumination.

After approaching the membrane, vesicles normally paused for $\sim 60 \mathrm{~ms}$ before disappearing. This dwell time near the membrane may include time for assembly of the SNARE complex and triggering of release by $\mathrm{Ca}^{2+}$ binding. Membrane dwell times limit the rate of vesicle replenishment and may therefore contribute to diminished release from rods at high temporal frequencies (Armstrong-Gold and Rieke, 2003). With strong depolarization, salamander cones can maintain release at $\sim 100$ vesicles/s per ribbon or 5 vesicles/s per docking site, suggesting that replenish- 
ment requires $\sim 200 \mathrm{~ms} /$ docking site (Bartoletti et al., 2010). This is longer than membrane dwell times in rods, suggesting that perhaps earlier steps (e.g., attachment to the ribbon) also regulate replenishment rates. Bullfrog saccular hair cells can maintain release at $\sim 500$ vesicles/s per ribbon or 12.5 vesicles/s per docking site (Parsons et al., 1994; Lenzi et al., 2002), suggesting that replenishment requires $\sim 80 \mathrm{~ms} /$ docking site. For this cell type, 60 ms dwell times would be essentially sufficient to explain replenishment. Dwell times can be influenced by the properties of exocytotic proteins (Ohara-Imaizumi et al., 2007), and these vary among cell types. Thus, dwell times of $\sim 200 \mathrm{~ms}$ were seen in bipolar cells (Zenisek et al., 2000), kiss-and-run fusion events in astrocytes are associated with dwell times of $\sim 1 \mathrm{~s}$ (Malarkey and Parpura, 2011), and dwell times for large dense-core vesicles in neuroendocrine cells are typically $>1 \mathrm{~s}$, although dwell times of $<300 \mathrm{~ms}$ have also been observed (Allersma et al., 2004).

Voltage clamping rods at $-70 \mathrm{mV}$ increased the number of immobilized vesicles near the membrane. During depolarizing stimulation, membrane-associated vesicles advanced deeper into the evanescent field of illumination, causing a transient brightening just before the abrupt fluorescence decline accompanying exocytosis. The magnitude of brightening suggests a final advance of $\sim 18 \mathrm{~nm}$. Membranes are $\sim 7.5 \mathrm{~nm}$ thick (Robertson, 1959; Yamamoto, 1963), and the SNARE complex is $\sim 12 \mathrm{~nm}$ long $\times 3 \mathrm{~nm}$ wide (Sutton et al., 1998). An advance of $18 \mathrm{~nm}$ is therefore consistent with SNARE-mediated merger of vesicle and plasma membranes. Bipolar cell vesicles (Zenisek et al., 2000) and large dense-core vesicles (Karatekin et al., 2008) also advanced $\sim 20 \mathrm{~nm}$ toward the membrane before fusion, but these movements occurred much earlier, preceding final fusion by $\sim 250 \mathrm{~ms}$ and $\sim 1$ s, respectively.

\section{Implications for rod neurotransmission}

The exocytotic $\mathrm{Ca}^{2+}$ sensor in rods and cones shows an unusually high $\mathrm{Ca}^{2+}$ sensitivity (Rieke and Schwartz, 1996; Thoreson et al., 2004; Sheng et al., 2007; Duncan et al., 2010). In cones, $\left[\mathrm{Ca}^{2+}\right]_{\mathrm{i}}$ at the base of the ribbon in darkness is therefore sufficient to stimulate release of a vesicle as soon as it is available for fusion (Jackman et al., 2009). This leads to a depletion of release sites at the base of the ribbon in darkness. The findings that rod release sites were depleted at membrane potentials near the dark resting potential and vesicles were immobilized at the membrane only when $\mathrm{Ca}^{2+}$ entry was inhibited (e.g., by holding rods at $-70 \mathrm{mV}$ or blocking $\mathrm{Ca}^{2+}$ channels) are consistent with a similar scenario in rods.

After depleting vesicles from the base of the ribbon, the rate of sustained release is limited by the rate at which vesicles can repopulate available release sites (Jackman et al., 2009; Oesch and Diamond, 2011). It has been proposed that this might reduce synaptic noise by uncoupling release events from the stochastic occurrence of individual $\mathrm{Ca}^{2+}$ channel openings (Jackman et al., 2009). However, if sustained release rates are governed by vesicle delivery, then variability in vesicle membrane dwell times could also introduce noise. Dwell times of pHrodo-loaded vesicles exhibited a relatively large SD of $23 \mathrm{~ms}$, but this may be primarily attributable to the image acquisition rate of $40 \mathrm{~ms} /$ frame. Higher temporal resolution measurements are needed to test whether ribbons regularize vesicle delivery.

Ribbons facilitate clustering of vesicles near $\mathrm{Ca}^{2+}$ channels and induce a maturation process to help vesicles become fusion competent (Heidelberger et al., 2002; Frank et al., 2010; Snellman et al., 2011). Similar to bipolar cells (Midorikawa et al., 2007; Zenisek, 2008), most release events triggered by depolarizing steps in rods occurred $<1 \mu \mathrm{m}$ from the nearest focal $\mathrm{Ca}^{2+}$ entry site (i.e., close to the ribbon). Sustained depolarization with 500 ms steps caused $\mathrm{Ca}^{2+}$ to spread throughout rod terminals and increased the frequency of release at ectopic, non-ribbon sites. However, even with sustained depolarization, release occurred more frequently near the ribbon than predicted by a random distribution of release events, consistent with results from other ribbon synapses showing that release-competent vesicles are concentrated near the ribbon (Zenisek, 2008; Frank et al., 2010; Snellman et al., 2011).

The increase in non-ribbon release accompanying sustained depolarization suggests that non-ribbon sites make a greater contribution to postsynaptic responses when rods are maintained in a continuously depolarized state as occurs in darkness. Maintained depolarization triggers the spread of $\mathrm{Ca}^{2+}$ throughout rod terminals by activating CICR (Krizaj et al., 1999, 2003; Cadetti et al., 2006; Suryanarayanan and Slaughter, 2006; Babai et al., 2010). Thus, non-ribbon release may be amplified by $\mathrm{Ca}^{2+}$ release from intracellular stores. Rod ribbons sit in a ridge-shaped projection that protrudes into a deep invagination within the terminal. Intracellular $\mathrm{Ca}^{2+}$ is released from endoplasmic reticulum that is found near the plasma membrane along the flanks of the invagination (Ungar et al., 1981; Mercurio and Holtzman, 1982; Babai et al., 2010), in the same regions of the synapse in which exocytotic omega figures were observed by electron microscopy (Zampighi et al., 2011). Non-ribbon release might also potentially occur at basal contacts between rods and bipolar cells outside of the invagination, although basal contacts are primarily devoid of vesicles (Lasansky, 1973). Whether located along the flanks of the invagination or at basal contacts, non-ribbon release sites would be farther than ribbon release sites from glutamate receptors found at the tips of horizontal and bipolar cell processes in the center of the invagination (Morigiwa and Vardi, 1999; Klooster et al., 2009). Although glutamate can diffuse throughout the photoreceptor synaptic cleft and reach quite distant receptors, the diffusional spreading of glutamate slows the kinetics of postsynaptic currents (Rao-Mirotznik et al., 1998; DeVries et al., 2006) and may also contribute to an elevation of basal glutamate levels in the cleft during maintained depolarization (Cadetti et al., 2008). Diffusional spreading of glutamate might therefore contribute to slow synaptic kinetics in rods (Schnapf and Copenhagen, 1982; Copenhagen et al., 1983; Rabl et al., 2005). However, amplifying release rates in darkness by recruiting additional nonribbon release sites might make it easier for postsynaptic neurons to detect decrements in release when rods hyperpolarize to light.

\section{References}

Abe H, Yamamoto TY (1984) Diurnal changes in synaptic ribbons of rod cells of the turtle. J Ultrastruct Res 86:246-251. Medline

Allersma MW, Wang L, Axelrod D, Holz RW (2004) Visualization of regulated exocytosis with a granule-membrane probe using total internal reflection microscopy. Mol Biol Cell 15:4658-4668. CrossRef Medline

Armstrong-Gold CE, Rieke F (2003) Bandpass filtering at the rod to secondorder cell synapse in salamander (Ambystoma tigrinum) retina. J Neurosci 23:3796-3806. Medline

Axelrod D (2001) Selective imaging of surface fluorescence with very high aperture microscope objectives. J Biomed Opt 6:6-13. CrossRef Medline

Babai N, Morgans CW, Thoreson WB (2010) Calcium-induced calcium release contributes to synaptic release from mouse rod photoreceptors. Neuroscience 165:1447-1456. CrossRef Medline

Balkema GW, Cusick K, Nguyen TH (2001) Diurnal variation in synaptic ribbon length and visual threshold. Vis Neurosci 18:789-797. CrossRef Medline

Bartoletti TM, Babai N, Thoreson WB (2010) Vesicle pool size at the salamander cone ribbon synapse. J Neurophysiol 103:419-423. CrossRef Medline 
Becherer U, Moser T, Stühmer W, Oheim M (2003) Calcium regulates exocytosis at the level of single vesicles. Nat Neurosci 6:846-853. CrossRef Medline

Bereiter-Hahn J, Fox CH, Thorell B (1979) Quantitative reflection contrast microscopy of living cells. J Cell Biol 82:767-779. CrossRef Medline

Betz WJ, Bewick GS (1992) Optical analysis of synaptic vesicle recycling at the frog neuromuscular junction. Science 255:200-203. CrossRef Medline

Bezzi P, Gundersen V, Galbete JL, Seifert G, Steinhäuser C, Pilati E, Volterra A (2004) Astrocytes contain a vesicular compartment that is competent for regulated exocytosis of glutamate. Nat Neurosci 7:613-620. CrossRef Medline

Cadetti L, Tranchina D, Thoreson WB (2005) A comparison of release kinetics and glutamate receptor properties in shaping rod-cone differences in EPSC kinetics in the salamander retina. J Physiol 569:773-788. CrossRef Medline

Cadetti L, Bryson EJ, Ciccone CA, Rabl K, Thoreson WB (2006) Calciuminduced calcium release in rod photoreceptor terminals boosts synaptic transmission during maintained depolarization. Eur J Neurosci 23:29832990. CrossRef Medline

Cadetti L, Bartoletti TM, Thoreson WB (2008) Quantal mEPSCs and residual glutamate: how horizontal cell responses are shaped at the photoreceptor ribbon synapse. Eur J Neurosci 27:2575-2586. CrossRef Medline

Cochilla AJ, Angleson JK, Betz WJ (1999) Monitoring secretory membrane with FM1-43 fluorescence. Annu Rev Neurosci 22:1-10. CrossRef Medline

Copenhagen DR, Ashmore JF, Schnapf JK (1983) Kinetics of synaptic transmission from photoreceptors to horizontal and bipolar cells in turtle retina. Vision Res 23:363-369. CrossRef Medline

DeVries SH (2001) Exocytosed protons feedback to suppress the $\mathrm{Ca}^{2+}$ current in mammalian cone photoreceptors. Neuron 32:1107-1117. CrossRef Medline

DeVries SH, Li W, Saszik S (2006) Parallel processing in two transmitter microenvironments at the cone photoreceptor synapse. Neuron 50:735748. CrossRef Medline

Dick O, tom Dieck S, Altrock WD, Ammermüller J, Weiler R, Garner CC, Gundelfinger ED, Brandstätter JH (2003) The presynaptic active zone protein bassoon is essential for photoreceptor ribbon synapse formation in the retina. Neuron 37:775-786. CrossRef Medline

Duncan G, Rabl K, Gemp I, Heidelberger R, Thoreson WB (2010) Quantitative analysis of synaptic release at the photoreceptor synapse. Biophys J 98:2102-2110. CrossRef Medline

Eggermann E, Bucurenciu I, Goswami SP, Jonas P (2012) Nanodomain coupling between $\mathrm{Ca}^{2+}$ channels and sensors of exocytosis at fast mammalian synapses. Nat Rev Neurosci 13:7-21. CrossRef Medline

Francis AA, Mehta B, Zenisek D (2011) Development of new peptide-based tools for studying synaptic ribbon function. J Neurophysiol 106:10281037. CrossRef Medline

Frank T, Rutherford MA, Strenzke N, Neef A, Pangršič T, Khimich D, Fetjova A, Gundelfinger ED, Liberman MC, Harke B, Bryan KE, Lee A, Egner A, Riedel D, Moser T (2010) Bassoon and the synaptic ribbon organize $\mathrm{Ca}^{2+}$ channels and vesicles to add release sites and promote refilling. Neuron 68:724-738. CrossRef Medline

Fuchs M, Sendelbeck A, Atorf J, Kremers J, Brandstätter JH (2013) Strain differences in illumination-dependent structural changes at mouse photoreceptor ribbon synapses. J Comp Neurol 521:69-78. CrossRef Medline

Gaffield MA, Betz WJ (2007) Synaptic vesicle mobility in mouse motor nerve terminals with and without synapsin. J Neurosci 27:13691-13700. CrossRef Medline

Glowatzki E, Fuchs PA (2002) Transmitter release at the hair cell ribbon synapse. Nat Neurosci 5:147-154. CrossRef Medline

He L, Wu XS, Mohan R, Wu LG (2006) Two modes of fusion pore opening revealed by cell-attached recordings at a synapse. Nature 444:102-105. CrossRef Medline

Heidelberger R, Sterling P, Matthews G (2002) Roles of ATP in depletion and replenishment of the releasable pool of synaptic vesicles. J Neurophysiol 88:98-106. Medline

Hoffman-Kim D, Diefenbach TJ, Eustace BK, Jay DG (2007) Chromophore-assisted laser inactivation. Methods Cell Biol 82:335-354. CrossRef Medline

Holt M, Cooke A, Neef A, Lagnado L (2004) High mobility of vesicles sup- ports continuous exocytosis at a ribbon synapse. Curr Biol 14:173-183. CrossRef Medline

Jackman SL, Choi SY, Thoreson WB, Rabl K, Bartoletti TM, Kramer RH (2009) Role of the synaptic ribbon in transmitting the cone light response. Nat Neurosci 12:303-310. CrossRef Medline

Karatekin E, Tran VS, Huet S, Fanget I, Cribier S, Henry JP (2008) A 20-nm step toward the cell membrane preceding exocytosis may correspond to docking of tethered granules. Biophys J 94:2891-2905. CrossRef Medline

Khimich D, Nouvian R, Pujol R, Tom Dieck S, Egner A, Gundelfinger ED, Moser T (2005) Hair cell synaptic ribbons are essential for synchronous auditory signalling. Nature 434:889-894. CrossRef Medline

Klooster J, Yazulla S, Kamermans M (2009) Ultrastructural analysis of the glutamatergic system in the outer plexiform layer of zebrafish retina. J Chem Neuroanat 37:254-265. CrossRef Medline

Korenbrot JI, Rebrik TI (2002) Tuning outer segment $\mathrm{Ca}^{2+}$ homeostasis to phototransduction in rods and cones. Adv Exp Med Biol 514:179-203. CrossRef Medline

Krizaj D, Bao JX, Schmitz Y, Witkovsky P, Copenhagen DR (1999) Caffeine-sensitive calcium stores regulate synaptic transmission from retinal rod photoreceptors. J Neurosci 19:7249-7261. Medline

Krizaj D, Lai FA, Copenhagen DR (2003) Ryanodine stores and calcium regulation in the inner segments of salamander rods and cones. J Physiol 547:761-774. CrossRef Medline

Lasansky A (1973) Organization of the outer synaptic layer in the retina of the larval tiger salamander. Philos Trans R Soc Lond B Biol Sci 265:471489. CrossRef Medline

Leduc M, Guay D, Leask RL, Coulombe S (2009) Cell permeabilization using a non-thermal plasma. New J Physics 11:115021. CrossRef

Lenzi D, Crum J, Ellisman MH, Roberts WM (2002) Depolarization redistributes synaptic membrane and creates a gradient of vesicles on the synaptic body at a ribbon synapse. Neuron 36:649-659. CrossRef

Malarkey EB, Parpura V (2011) Temporal characteristics of vesicular fusion in astrocytes: examination of synaptobrevin 2-laden vesicles at single vesicle resolution. J Physiol 589:4271-4300. CrossRef Medline

Matthews G, Fuchs P (2010) The diverse roles of ribbon synapses in sensory neurotransmission. Nat Rev Neurosci 11:812-822. CrossRef Medline

Mattheyses AL, Axelrod D (2006) Direct measurement of the evanescent field profile produced by objective-based total internal reflection fluorescence. J Biomed Opt 11:014006. CrossRef Medline

Mercer AJ, Thoreson WB (2011) The dynamic architecture of photoreceptor ribbon synapses: cytoskeletal, extracellular matrix, and intramembrane proteins. Vis Neurosci 28:453-471. CrossRef Medline

Mercer AJ, Rabl K, Riccardi GE, Brecha NC, Stella SL Jr, Thoreson WB (2011) Location of release sites and calcium-activated chloride channels relative to calcium channels at the photoreceptor ribbon synapse. J Neurophysiol 105:321-335. CrossRef Medline

Mercurio AM, Holtzman E (1982) Smooth endoplasmic reticulum and other agranular reticulum in frog retinal photoreceptors. J Neurocytol 11:263-293. CrossRef Medline

Midorikawa M, Tsukamoto Y, Berglund K, Ishii M, Tachibana M (2007) Different roles of ribbon-associated and ribbon-free active zones in retinal bipolar cells. Nat Neurosci 10:1268-1276. CrossRef Medline

Morgans CW (2001) Localization of the alpha(1F) calcium channel subunit in the rat retina. Invest Ophthalmol Vis Sci 42:2414-2418. Medline

Morigiwa K, Vardi N (1999) Differential expression of ionotropic glutamate receptor subunits in the outer retina. J Comp Neurol 405:173-184. CrossRef Medline

Nachman-Clewner M, St Jules R, Townes-Anderson E (1999) L-type calcium channels in the photoreceptor ribbon synapse: localization and role in plasticity. J Comp Neurol 415:1-16. CrossRef Medline

Oesch NW, Diamond JS (2011) Ribbon synapses compute temporal contrast and encode luminance in retinal rod bipolar cells. Nat Neurosci 14:1555-1561. CrossRef Medline

Ohara-Imaizumi M, Fujiwara T, Nakamichi Y, Okamura T, Akimoto Y, Kawai J, Matsushima S, Kawakami H, Watanabe T, Akagawa K, Nagamatsu S (2007) Imaging analysis reveals mechanistic differences between first- and second-phase insulin exocytosis. J Cell Biol 177:695-705. CrossRef Medline

Oheim M, Loerke D, Stühmer W, Chow RH (1999) Multiple stimulationdependent processes regulate the size of the releasable pool of vesicles. Eur Biophys J 28:91-101. CrossRef Medline

Parsons TD, Lenzi D, Almers W, Roberts WM (1994) Calcium-triggered 
exocytosis and endocytosis in an isolated presynaptic cell: capacitance measurements in saccular hair cells. Neuron 13:875-883. CrossRef Medline

Rabl K, Cadetti L, Thoreson WB (2005) Kinetics of exocytosis is faster in cones than in rods. J Neurosci 25:4633-4640. CrossRef Medline

Rao-Mirotznik R, Buchsbaum G, Sterling P (1998) Transmitter concentration at a three-dimensional synapse. J Neurophysiol 80:3163-3172. Medline

Rea R, Li J, Dharia A, Levitan ES, Sterling P, Kramer RH (2004) Streamlined synaptic vesicle cycle in cone photoreceptor terminals. Neuron 41:755766. CrossRef Medline

Richards DA, Bai J, Chapman ER (2005) Two modes of exocytosis at hippocampal synapses revealed by rate of FM1-43 efflux from individual vesicles. J Cell Biol 168:929-939. CrossRef Medline

Rieke F, Schwartz EA (1996) Asynchronous transmitter release: control of exocytosis and endocytosis at the salamander rod synapse. J Physiol 493: 1-8. Medline

Robertson JD (1959) The ultrastructure of cell membranes and their derivatives. Biochem Soc Symp 16:3-43. Medline

Schmitz F (2009) The making of synaptic ribbons: how they are built and what they do. Neuroscientist 15:611-624. CrossRef Medline

Schmoranzer J, Goulian M, Axelrod D, Simon SM (2000) Imaging constitutive exocytosis with total internal reflection fluorescence microscopy. J Cell Biol 149:23-32. CrossRef Medline

Schnapf JL, Copenhagen DR (1982) Differences in the kinetics of rod and cone synaptic transmission. Nature 296:862-864. CrossRef Medline

Serulle Y, Sugimori M, Llinás RR (2007) Imaging synaptosomal calcium concentration microdomains and vesicle fusion by using total internal reflection fluorescent microscopy. Proc Natl Acad Sci U S A 104:1697-1702. CrossRef Medline

Sheng Z, Choi SY, Dharia A, Li J, Sterling P, Kramer RH (2007) Synaptic $\mathrm{Ca}^{2+}$ in darkness is lower in rods than cones, causing slower tonic release of vesicles. J Neurosci 27:5033-5042. CrossRef Medline

Singer JH, Lassová L, Vardi N, Diamond JS (2004) Coordinated multivesicular release at a mammalian ribbon synapse. Nat Neurosci 7:826-833. CrossRef Medline

Snellman J, Mehta B, Babai N, Bartoletti TM, Akmentin W, Francis A, Matthews G, Thoreson W, Zenisek D (2011) Acute destruction of the synaptic ribbon reveals a role for the ribbon in vesicle priming. Nat Neurosci 14:1135-1141. CrossRef Medline

Spiwoks-Becker I, Glas M, Lasarzik I, Vollrath L (2004) Mouse photoreceptor synaptic ribbons lose and regain material in response to illumination changes. Eur J Neurosci 19:1559-1571. CrossRef Medline

Steyer JA, Horstmann H, Almers W (1997) Transport, docking and exocytosis of single secretory granules in live chromaffin cells. Nature 388:474478. CrossRef Medline

Sund SE, Swanson JA, Axelrod D (1999) Cell membrane orientation visualized by polarized total internal reflection fluorescence. Biophys $\mathrm{J} 77$ : 2266-2283. CrossRef Medline

Suryanarayanan A, Slaughter MM (2006) Synaptic transmission mediated by internal calcium stores in rod photoreceptors. J Neurosci 26:17591766. CrossRef Medline

Sutton RB, Fasshauer D, Jahn R, Brunger AT (1998) Crystal structure of a SNARE complex involved in synaptic exocytosis at 2.4 A resolution. Nature 395:347-353. CrossRef Medline
Szikra T, Krizaj D (2006) The dynamic range and domain-specific signals of intracellular calcium in photoreceptors. Neuroscience 141:143-155. CrossRef Medline

Thoreson WB, Nitzan R, Miller RF (2000) Chloride efflux inhibits single calcium channel open probability in vertebrate photoreceptors: chloride imaging and cell-attached patch-clamp recordings. Vis Neurosci 17:197_ 206. Medline

Thoreson WB, Rabl K, Townes-Anderson E, Heidelberger R (2004) A highly $\mathrm{Ca}^{2+}$-sensitive pool of vesicles contributes to linearity at the rod photoreceptor ribbon synapse. Neuron 42:595-605. CrossRef Medline

tom Dieck S, Altrock WD, Kessels MM, Qualmann B, Regus H, Brauner D, Fejtová A, Bracko O, Gundelfinger ED, Brandstätter JH (2005) Molecular dissection of the photoreceptor ribbon synapse: physical interaction of Bassoon and RIBEYE is essential for the assembly of the ribbon complex. J Cell Biol 168:825-836. CrossRef Medline

Toomre D, Steyer JA, Keller P, Almers W, Simons K (2000) Fusion of constitutive membrane traffic with the cell surface observed by evanescent wave microscopy. J Cell Biol 149:33-40. CrossRef Medline

Townes-Anderson E, MacLeish PR, Raviola E (1985) Rod cells dissociated from mature salamander retina: ultrastructure and uptake of horseradish peroxidase. J Cell Biol 100:175-188. CrossRef Medline

Tsuboi T, Zhao C, Terakawa S, Rutter GA (2000) Simultaneous evanescent wave imaging of insulin vesicle membrane and cargo during a single exocytotic event. Curr Biol 10:1307-1310. CrossRef Medline

Ungar F, Piscopo I, Holtzman E (1981) Calcium accumulation in intracellular compartments of frog retinal rod photoreceptors. Brain Res 205: 200-206. CrossRef Medline

Van Hook MJ, Thoreson WB (2013) Simultaneous whole cell recordings from photoreceptors and second-order neurons in an amphibian retinal slice preparation. J Vis Exp e50007.

Wu Y, Yeh FL, Mao F, Chapman ER (2009) Biophysical characterization of styryl dye-membrane interactions. Biophys J 97:101-109. CrossRef Medline

Wu Y, Ma L, Cheley S, Bayley H, Cui Q, Chapman ER (2011) Permeation of styryl dyes through nanometer-scale pores in membranes. Biochemistry 50:7493-7502. CrossRef Medline

Yamamoto T (1963) On the thickness of the unit membrane. J Cell Biol 17:413-421. CrossRef Medline

Zampighi GA, Schietroma C, Zampighi LM, Woodruff M, Wright EM, Brecha NC (2011) Conical tomography of a ribbon synapse: structural evidence for vesicle fusion. PLoS One 6:e16944. CrossRef Medline

Zenisek D (2008) Vesicle association and exocytosis at ribbon and extraribbon sites in retinal bipolar cell presynaptic terminals. Proc Natl Acad Sci U S A 105:4922-4927. CrossRef Medline

Zenisek D, Steyer JA, Almers W (2000) Transport, capture and exocytosis of single synaptic vesicles at active zones. Nature 406:849-854. CrossRef Medline

Zenisek D, Steyer JA, Feldman ME, Almers W (2002) A membrane marker leaves synaptic vesicles in milliseconds after exocytosis in retinal bipolar cells. Neuron 35:1085-1097. CrossRef Medline

Zenisek D, Horst NK, Merrifield C, Sterling P, Matthews G (2004) Visualizing synaptic ribbons in the living cell. J Neurosci 24:9752-9759. CrossRef Medline 